\title{
The Salt Lakes: Pāśupatas and Śaiva Centers in Jambumārga
}

This chapter continues the survey of the Skandapurāna's mapping of the Pāśupata landscape in the area of northeast Rajasthan traditionally known as Sapādalakșa. A vast, arid region dominated by spurs of the Aravelli Mountain Range, Sapādalakṣa is home to three large salt lakes: Ḍị̂aānā, Sāmbhar (Śākambharī), and Sikar. These lakes and their environs constituted a critical zone of economic, political, and religious development from the 7 th through the 1oth century $\mathrm{CE}$ as active centers of exchange along the northern caravan routes, where trade in salt, horses, and other goods flourished. Asserting dominance over the Salt Lakes region facilitated the rise of the early Cāhamāna rulers, whose descendants were the Chauhan clan of Rajputs celebrated in the later bardic chronicles of Rajasthan. The prosperous regional economy also attracted Śaiva religious specialists, who found generous patrons among the socially ascendant merchant families and local elites. While the precise location of Jambumārga remains uncertain, I propose that this Salt Lakes region presents a compelling possibility for the locale that the SP identifies with Lakuliśa's third student, Gārgya.

Epigraphic and material sources indicate that Sapādalakṣa was a preeminent center for the institutionalization of Śaiva religiosity in the early medieval period and, by the early 1oth century, networks of Pāśupata religious specialists occupied positions of social prominence. The most important sites for Pāśupata activity in the region were Mt. Harșa, an extensive royal religious complex near Sikar, and Kāman, a frontier merchant town located $275 \mathrm{~km}$ to the east. The historical sources from these places show the ability of Siva religion to catalyze remarkable social synergies between individuals and communities from a wide variety of social strata. At the same time, each of these places developed a distinct and locally inflected religious landscape. At Mt. Harșa, the public works converging around Śaivism proved a powerful tool for the earliest articulations of the Cāhamāna royal personae as well as the piety of the resident Pāśupata ascetics. By contrast, sources from Kāman articulate an irenic and socially supported vision of Śaivism adapted to model the aspirations of an upwardly mobile community of merchants and artisans. 


\section{Geographic Context}

The economic and political development of the 'Salt Lakes' region exemplifies well the patterns that characterized Early Medieval India: the expansion of agrarian and settlement areas in what had previously been uncultivated or sparsely-inhabited regions, combined with the increased power and influence of localized political elites, many styling themselves rājaputras. The move of the Imperial Pratīhāras from their early capital at Mandor, north of Jodhpur in Rajasthan, toward the highly coveted city of Kanauj, created an opportunity for local clans to pursue new political aspirations, and marked the inception of the Rajput dynasties that would come to dominate the area in subsequent centuries. Inscriptions from Sapādalakșa attest to the active socialization and economic growth in new spaces of what had once been the edges of the northwest frontier - a pattern indicated by the increased use of terms for small market towns (e.g. hața; maṇdapika $)^{1}$ and reference to fortified areas (e.g. koțta). The fortified towns founded by local rulers became active commercial centers for merchants and traders (e.g. vaniks; śreșthis) who established new communities in these emergent settlements. ${ }^{2}$

The growth of religious institutions in Sapādalakșa ${ }^{3}$ was intimately connected with patterns in the regional economy and settlement expansion. By the 8th century the building and endowing of temples to Śiva became increasing popular, a development represented in the epigraphic sources as a cooperative enterprise involving religious specialists, merchant communities, guilds, artisans, and local political elites. These religious centers controlled significant immovable assets (i.e. market stalls and fields) and participated in the monetized economy through rents paid in cash and taxes paid to the temple by guilds and traders. The region's remarkable artistic legacy is indicative of an

1 While mandapikā is typically understood as a 'toll-station' or 'customs house,' it came to refer to the larger marketplace and the surrounding settlement as well. D.C. Sircar, Indian Epigraphical Glossary, s.v. mandapikā.

2 For examples from Early Medieval Rajasthan see e.g. D.C. Sircar, "Khandela Inscription of Year 201," EI 34 (1961-62): 159-163; B.Ch. Chhabra, "Mandkila Tal Inscription," EI 34 (1961-62): 77-90; B.Ch. Chhabra, "Sakrai Stone Inscription; V.S., 699," EI 27: 27-33. See Chapter II for similar examples from Uparamāla.

3 The term 'sapādalakșa' is a general heading used to refer to territories with $1^{1 / 4}$ lakh villages. The Kumārīkhanda of the Skandapurāna refers to several such 'sapādalakșas'. The Cāhamānas belonged specifically to the Śākambharasapādalakṣa. See Dasaratha Sharma, Early Chauhan Dynasties (New Delhi: S. Chand \& co, 1959), 11-12. Sharma cites later Muslim historians who call this territory 'Siwālik,' which contained 125,00o towns and villages and had Ajmer as its capital. 


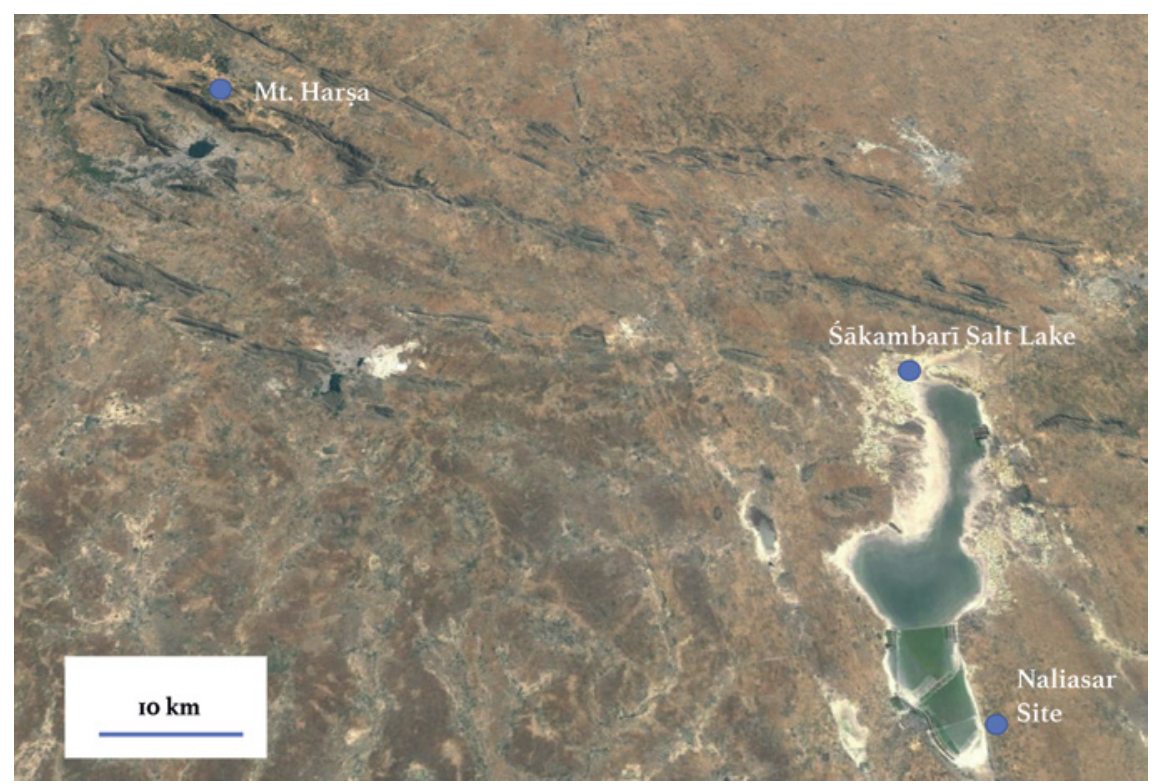

FIGURE 35

Satellite map showing Mt. Harṣa and Śākambharī Salt Lake GOOGLE EARTH

economic surplus substantial enough to support ambitious public works and monumental religious institutions.

My research has revealed strong connections between the siting of Śaiva religious centers and the area west of the Aravelli Mountains where there are numerous salt lakes. ${ }^{4}$ The largest of these lakes are Dịdvānā (ancient Ḍeṇḍavānaka), Sāmbhar (Śākambharī), and Sikar [Figure 35]. The production, harvesting, and sale of salt has been, and continues to be, the major commercial enterprise dominating the regional economy, not to mention a source of political competition. ${ }^{5}$ Architectural and iconographic remains from

4 M.D. Kajale \& B.C. Deotare, "Field Observations and Lithostratigraphy of the Three Salt Lake Deposits in Indian Desert of Western Rajasthan," Bulletin of the Deccan College Research Institute 53 (1993): 117-134; V.C. Misra, The Geography of Rajasthan (New Delhi: National Book Trust, 1967).

5 Competition for control over this area and salt industry raged fiercely in the 14th century between the Sultans of Delhi, rulers of Gujarat, and the Rānās of Mewar. See K.C. Jain, Ancient Cities and Towns of Rajasthan: A Study of Culture and Civilization (Delhi: Motilal Banarsidass, 1972), 192-3. Complex networks for salt manufacture and trade were also observed and reported by colonial officials in Rajputana. It is not surprising that establishing a monopoly on salt production and trade was one of the first undertakings of the British East India Company in 1780. See Richard M. Dane, "The Manufacture of Salt in India," Journal of the Royal Society of Arts 72 (1924): 402-418. 


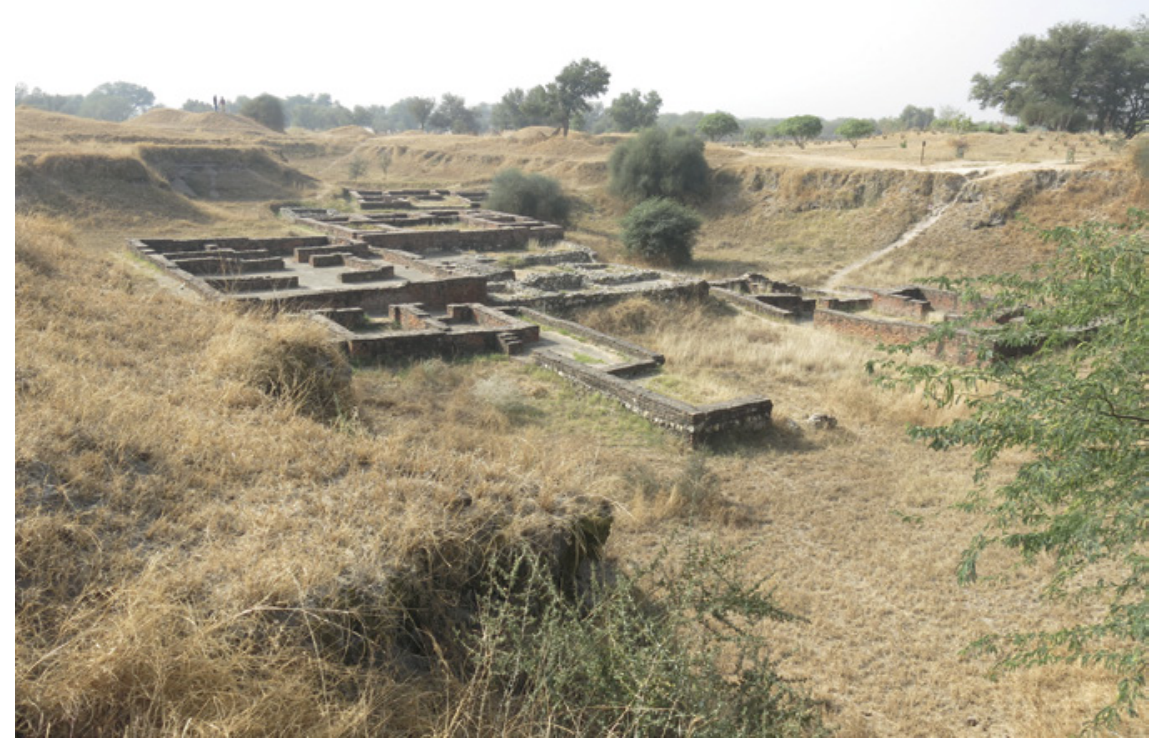

FIGURE $36 \quad$ Naliasar excavation site

the southern border of Sapādalakșa (i.e. the area around the modern capital of Jaipur) also preserve an invaluable material archive of the region's artistic traditions. ${ }^{6}$ There is, however, little evidence for a dominant Śaiva presence, or a specifically Pāśupata influence, in this area. Although one could invoke the common criticism that the evidence from this historical period is too fragmentary to support any firm conclusions, it is nonetheless significant that in the material record from the southern areas of Sapādalakșa there is little that points to an institutionalized Śaivism. The most significant Śaiva material is preserved in the Salt Lakes region where the social, political, and economic conditions supported a flourishing Śaiva religiosity and networks of religious specialists.

The largest of the salt lakes, Śăkambharī was also the site of an extensive ancient settlement known as Naliasar. Much of the roughly $6 \mathrm{~km}$ excavation area has been filled in, but some remains of the habitation area are still visible [Figure 36]. Reports published from a series of excavations record the

6 Important monumental sites from this area include the stepwell at Choțī Khāṭū (c. 8th century), the massive stepwell at Ābānerī (c. 8th century) and the slightly later temple of Harṣatmātā (c early gth century). 
discovery of a large settlement and industrial center-e.g. extensive structural foundations from the Kușāna and Gupta periods, large finds of terracotta, pottery, and materials for stone-cutting and polishing, as well as terracotta votive sculptures. ${ }^{7}$ The enormous deposits of iron slag, the refuse of large-scale craft production, found in the course of excavation suggests craft specialization and production. Site stratigraphy dates the earliest layers of activity from the 3rd-4th century $\mathrm{CE}$, with a peak of activity and building expansion between the $5^{\text {th }}$ and the 7 th centuries. Settlement continued in subsequent centuries, but the stratigraphy indicates that new construction slowed after the 8th century. The chronology of the site supports my working hypothesis that Naliasar was the Jambumārga of the SP. ${ }^{8}$ In addition to conforming to geographical indications for Jambumārga found in the Mahäbhärata, Naliasar's stratigraphy indicates a high point of activity between the $5^{\text {th }}$ and the $7^{\text {th }}$ century, temporal horizons that accord with the rise and fall of Jambumārga's popularity in the literary sources. Jambumārga was evidently a well-known locale at the time of the Skandapurāna's composition in the late 6th-early 7 th century, yet the absence of references to this place in later sources suggests it had declined as a prosperous and culturally significant locale. While the prominence of Nailasar may have waned after the 8th century, regional economy and religion continued to be oriented around the Śākambharī Salt Lake.

\section{Politics \& Prestigious Places}

By the 8th century, a substantial expanse of northwest India was controlled by the Imperial Pratīhāras, whose power was augmented significantly by Mihira Bhoja (c. 836-892) in the second half of the 9th century. The success of this ruling family was due, in large part, to the relatively stable network of local clans they were able to mobilize in their support. These networks would have been of critical importance as the Pratīhāras sought to enhance their royal prestige

7 I summarize the findings reported in T.H. Hendley, "Buddhist Remains near Sambhar, in Western Rajputana, India," Journal of the Royal Asiatic Society 17.1 (1883): 29-37; D.R. Sahni, Archaeological Remains and Excavations at Sambhar (Jaipur: Jaipur State Dept, undated); A. Ghosh, An Encyclopedia of Indian Archaeology, vol. 2 (New Delhi: Munshiram Manoharlal, 1989), s.v. Sambhar.

8 The precise location of Jambumārga is unknown. According to the Mahäbhärata 3.80.59-61 it lay somewhere on a trade and pilgrimage route linking the ancient port of Broach in Gujarat (located to the south of Karvan on the mouth of the Narmadā River) with Puṣkara in modern Rajasthan. References to Jambumārga in the purānas are presented by Bisschop (Sects and Centers, 209). See also N.L. Dey, The Geographical Dictionary of Ancient and Medieval India (3rd ed. Delhi, 1971). 
by leaving their early stronghold at Mandor (i.e. Māṇạavyapura) to establish a capital much further east, at Kanauj, the political center of the Gangetic north for centuries to come. The Śākambharī Cāhamānas were one such local family whose military feats and marriage alliances served to distinguish them within the Pratīhāra court. ${ }^{9}$ Notably, the Cāhamāna Gūvaka II solidified his ties to the Pratīhāras through the marriage of his sister, Kalāvatī, to Bhoja. But the Cāhamānas were not destined to remain subordinate to the Pratīhāras. By the 11th century they controlled much of northeast Rajasthan. Gaining control over the Salt Lakes region and the Śăkambharī Lake, specifically, provided the catalyst for their political ascendancy.

The early history of the Sākambharī Cāhamānas is rather obscure. ${ }^{10}$ The literary and epigraphic sources most commonly cited in the historiography were composed centuries after their rule. ${ }^{11}$ Certainly we must be cautious in using these accounts; but if we overlook the vagaries of dynastic genealogies and accounts of military exploits, the one stable feature of the Cāhamāna narrative is geography. In both the literary sources and in their earliest inscriptions, the Cāhamānas are represented as an emplaced polity deeply rooted in the Sapādalakșa region and, more specifically, the area between Puṣkara and their ancestral homeland, a tract called Ananta, near Sikar. ${ }^{12}$ Ananta is used as a toponym first in the mid-1oth century Harșa inscription that identifies it with the Cāhamāna homeland and as the place where Vākpati, grandfather of Cāhamāna Vigraharāja II, was attacked by a rival named Kṣamāpāla. Epigraphic and material evidence permits an even more precise localization of Cāhamāna sovereignty around two prominent features of the landscape of

9 Members of the Guhila clans were important players in the expansion and support of the Pratīhāra court. The inscription of Guhila Bālāditya records the various deeds undertaken in service of the Pratīhāras. D.R. Bhandarkar, "Chatșu Inscription of Baladitya," EI 12 (1913-14): 9-17; Sharma, Early Chauhan Dynasties, 26.

10 The Cāhamānas, like other medieval kinship groups, were comprised of a number of regionally specific lineage groups. Other, later Cāhamāna lineages occupied Broach in Gujarat and Pratapgarh, and Nadol in Rajasthan.

11 D.S. Sharma's authoritative study of the Cāhamānas relies on late medieval literary sources like the Prthvirājavijaya, Prabandhakośa, and the Khummāna Rāso. Sharma, Early Chauhan Dynasties, 14-22. The genealogy recorded in the Bijolia Inscription (VS 1226/1170 CE) is also relatively late. A.K. Vyas, "Bijolia Rock Inscription of Chahamana Somesvara V.S. 1226," EI 26 (1941): 84-112.

12 See below; Verse 16. This place is mentioned again in the 13th century Bijolia Inscription as the homeland of the Cāhamāna Sāmanta. Here it also appears to be a regional designation as Sāmanta is reportedly from Ahichatrapura within the Ananta region. Vyas, "Bijolia Inscription," Verses 11-12; Sharma, Early Chauhan Dynasties, 10-13. 
Ananta: the Śākambharī Lake ${ }^{13}$ and Mt. Harṣa. From atop the imposing Mt. Harșa, the Cāhamānas proclaimed their status as independent rulers in a massive stone inscription (dated VS 1030/973 CE) memorializing the endowment of a monumental temple for their tutelary deity (kuladeva), Śiva, eulogized as the Lord Harșa.

Existing historiography on the period attributes this elevation in Cāhamāna rank to their Pratīhāra ties, yet these decontextualized perspectives minimize the critical role of geography and landscape in this history. ${ }^{14}$ I propose an alternative hypothesis that emphasizes geopolitics. The Cāhamānas' political success was contingent upon the ability of these rulers to exert control over places of regional economic and political prestige within the topography of Sapādalakșa and to shape these places both symbolically and materially, though building and donative practices. Claiming two of the regional landscape's most prominent features was a deft political maneuver that allowed the Cāhamānas to reinforce and materialize their own royal power through control of the physical terrain itself. This political strategy was not simply a symbolic gesture. By commanding the Salt Lakes region, the Cāhamānas would have been able to monopolize the lucrative salt trade so integral to the regional economy. At the same time, by overseeing the Śăkambharī-Harșa route, they could monitor the critical transregional flow of goods that ran north from Ujjain, via Puṣkara, to the market towns of the northwest and east to Mathurā. The regional economy contributed to the religious landscape as well. As I discuss below, taxes remitted by salt merchants and horse traders were used to fund the temple complex at Mt. Harṣa.

Religious life in medieval Sapādalakșa was inextricably bound up in the region's politics, the textures and complexities of which tend to be obscured by a scholarly focus on the fortunes of the Pratīhāras. While these rulers left a significant corpus of inscriptions, the majority of these are copper plates recording gifts to brahmins. No inscriptions recording the construction of temples

13 The earliest of the Cāhamāna rulers that can be connected with the Lake is Vigraharāja II, but as Sharma notes, the fourth chapter of the Prthviräjavijaya explicitly connects the 7th century Cāhamāna ruler, Vāsudeva with the Sāmbhar Lake, which was supposedly given to the king as a gift by a vidhyādhara. Sharma, Early Chauhan Dynasties, 23.

14 The Śākambharī Cāhamānas are discussed in Chapters 33 of EITA 2.2 and Chapters 50, \& 60 of EITA 2.3. M.A. Dhaky's entry (Chapter 50, p. 95) is particularly imaginative in charting the expansion of the Cāhamāna power through the defeat of various Pratīhāra generals and subordinates. Since Dhaky cites no primary sources to support his account, we must assume he is expanding upon and embellishing the narrative given in Sharma's monograph. 
have survived. ${ }^{15}$ The seeming reluctance of rulers of such expansive powers to engage in temple-based donative practices and the quotidian activities of temple care and management is a widespread historical phenomenon that, no doubt, has multiple explanations and contingencies. With that caveat, it is important to note that the act of endowing a temple or enshrining a deity created a tangible, and often enduring, link between the donor and a specific place or monument. Such practices would have served the interests of an emerging, emplaced polity like the Śākambharī Cāhamānas, whose ability to inscribe themselves upon the regional landscape served as a highly visible manifestation of their political prowess. When they became independent sovereigns in the 9th-1oth century, the rulers designated Mt. Harșa as their royal center. This act implies that both this remarkable site of cultural magnetism and Śaiva devotion, and the established network of religious specialists in residence there, were tied closely to an ascendant Cāhamāna political persona.

\section{$3 \quad$ Siva and the Mountain}

The remains of the temple complex at Mt. Harșa preserve significant evidence for religious life in Sapādalakșa and reflect the ways in which monuments were used to materialize ties between the power of a deity and that of pious patrons. At Harsa, these connections were communicated through the architecture and iconography of the temples and via the medium of a monumental stone inscription ${ }^{16}$ [Figure 37]. Like the temple to which it was affixed, this inscription evokes power, substance, and permanence. In addition to contributing a new material presence, the inscription also provides a new rhetorical frame

15 The only clear epigraphic evidence for Pratīhära building practices comes from the inscription at Sāgar Tāl, a tank just outside Gwalior. This record refers to the building of a palace complex or seraglio (antahpurapuram). R.C. Majumdar, "The Gwalior Prasasti of the Gurjara-Pratihara King Bhoja," EI 18 (1925): 99-114; Sircar, Select Inscriptions II, 24246. This record is also discussed in M. Willis, "Royal Patronage," in Gods, Guardians, and Lovers, eds. V. Desai \& D. Mason (New York: Asia Society Galleries, 1993), 49-65.

16 The inscription was originally found on the mountain amongst the rubble of the central temple and is now housed in the Sikar Government Museum. The text has been edited three times: E. Dean, "Description of the Ruins of an Ancient Temple at Harsha, in Shekáwatí," Journal of the Asiatic Society of Bengal 4 (1835): 361-400; F. Kielhorn, "Harsha Stone Inscription of the Chahamana Vigraharaja," EI 2 (1894): 116-140; D.R. Bhandarkar, "Some Published Inscriptions Reconsidered. 1. Harsha Stone Inscription of Vigraharāja," IA 42 (1913): 57-64. As reported by Kielhorn, the inscription was discovered by G.E. Rankin and E. Dean in 1834 . 


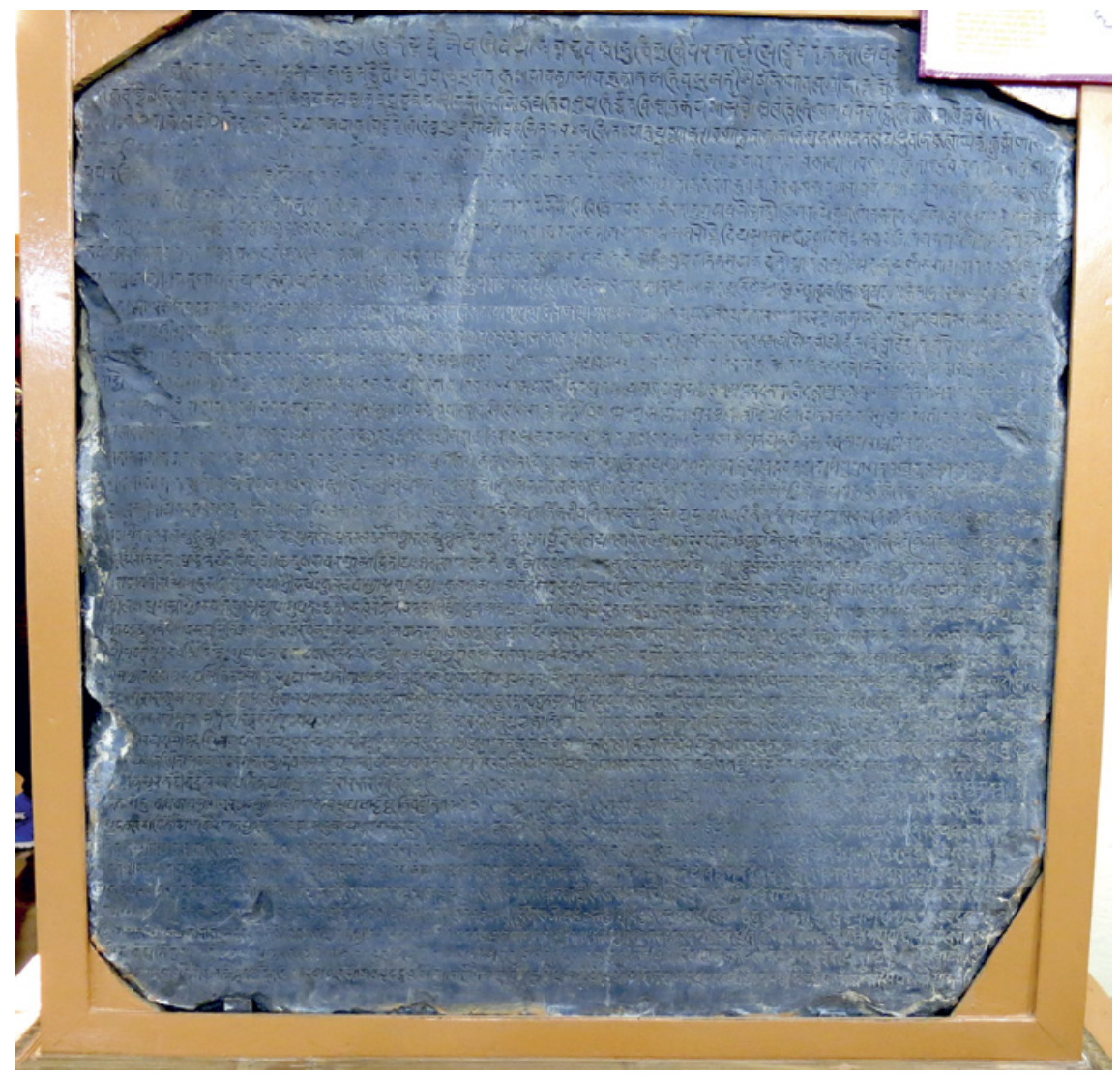

FIGURE 37 Harșa stone inscription

SIKAR GOVERNMENT MUSEUM

for the mountain by transforming it into the sanctified space of the Cāhamāna tutelary deity.

The text can be divided into four thematic sections. The first of these includes praise of Siva and the beauty of the mountain itself. This is followed by an extensive royal eulogy detailing the exploits and victories of the Cāhamānas and their donations to the shrine of their kuladeva, Lord Harșa. The temple that the inscription commemorates was reportedly completed in VS $1013 / 956 \mathrm{CE} .{ }^{17}$ The third section praises the lineage of resident Pāsupatas and commemorates

17 There are three dates recorded in the inscription: 1) VS 1013/956 CE, the date at which the temple constructed by Allața was reportedly completed. 2) VS 1027/970 CE, the date of Allata's death. 3) VS 1030/973 CE, the concluding date for subsequent donations made to the temple after its completion. 
their donations and pious acts. The concluding prose section records subsequent donations made prior to VS 1030/973 CE.

\subsection{Locating Lord Harșa}

Following the opening invocation of Ganeśa, the poet begins a eulogy of the Lord Paśupati who dwells on the mountain peak as the Lord Harșa. The epithet Harșa refers to a specific manifestation of Śiva as the tutelary deity of the mountain. The poet then expands upon this regional significance with a creative etymology that explains the origins of the epithet 'Harșa' using the tale of Siva's destruction of Tripura, the triple city of the demon sons of Tāraka. A famous deed of Śiva popularized in the Mahābhārata, here the legend is expanded to include a scene at Mt. Harșa. ${ }^{18}$

He who-full of joy (harșa) after he incinerated the enemies of the gods at Tripura with his burning arrow (and) was worshipped by a multitude of joyful gods led by Indra, who praised and bowed to him-took up residence on the two mountain peaks under the very name Harșa out of favor for Bhārata, may that moon-crested one, now with a second residence, dwell (here) in the form of the linga for your well-being. [7]

When the gods had seen his true form emerging, bewildering the creatures with its explosion of light in the form of the mighty fire from the socket of his eye, clouding the quarters of the earth with dense thick smoke from the trees licked by flames all around, making a terrible noise in the fury of its course, [the form that] pierced the five-arrowed god [Kāma] - they feared, "could this really be the apocalypse come ahead of schedule?" [8]

Let this mountain called Harșa, which grazes the clouds on high (and) on which the deity named Harșa, the destroyer of Pura, resides, purify you! [9]

CECIL $^{19}$

18 Mahābhärata 8.24.

19 These and all subsequent citations of the text are reproduced from Kielhorn's edition. The translations are my own.

nūnaṃ vānāgnidagdhattripurasuraripu $[$ r jā] taharșaḥ saharșair indrādyair devavrndaị̣ kṛtanutinatibhị̣ pūjyamāno 'ttra śaile /

yo 'bhūn nāmnāpi harșo giriśikharabhuvor bhāratānugrahāya

sa stād vo lingarūpo dviguṇitabhavanaś candramaulih śivāya // 7//

(Sragdharā)

niryannettrā $[n d ̣][$ bhā]ṇ̣̂ānaṇudahanaruciploṣasambhrāntasattvaṃ

prāntajvālāvalị̣hadrumabahalamahādhūmadhūmrāyitāśam/

samirambhārambhabhīmasvanam asamaśarocchedi yasyāśaśañke

drṣtvā devaih [sva]rūpam kim iya $[\mathrm{m}]$ asamaye saminhtir bbobhuve[dya] //8// 
In a manner characteristic of the literary genres of purāna and māhātmya these verses work to incorporate the specific locale of Mt. Harșa within the Śaiva mythic topography, writ large. This localization of sanctity involved the mapping of a rhetorical landscape in which temporal and geographic distinctions were effectively collapsed in order to elevate this site of regional sanctity by subsuming it within the established Śaiva mythology. This was accomplished in a threefold manner: 1 ) by the repetition of the name Harsa, which effectively assimilates the physical terrain of the mountain with the deity, Siva, who is said to dwell there in person. 2) The epithet 'Harșa' (i.e. joy) is then used to create a further layer of significance, as this 'joy' was expressed following Śiva's victory over Tripura, a victory also celebrated on Mt. Harșa 3) Finally, the text expresses yet another level of connection in Verse 7 by introducing Mt. Harșa as Śiva's second mountain abode, a terrestrial counterpart to his celestial mountain home. Moreover, the compound dvigunitabhavana in Verse 7 can also refer to his specific manifestation as the linga enshrined in the temple (i.e. his lingarūpa) and his divine form that dwells on the mountain. The two kinds of abodes then being the linga and the mountain. A similar duality is expressed in the compound girisikharabhuvos which I interpret as a reference to the two peaks of Mt. Harșa and Mt. Kailāsa. ${ }^{20}$ This verse expresses the poet's and patrons' desire to model Mt. Harșa as a sanctified space on earth that replicates Śiva's divine landscape-precisely the sentiment expressed in Verse 44, which refers to the temple as being "like a part of heaven" (svargakhandam iva).

The verses quoted above make clear that the mountain is empowered and sanctified by virtue of its affiliations with Śiva and important events in his mythology. The concluding verses of the opening section propose an even more intimate association that is derived from the presence of the Lord himself and the inseparability of the deity from the physical landscape. While acknowledging that the landscape itself appears far from paradisal, the poet explains that Siva's presence transforms the mountain into a supremely beautiful place.

The cascades of the Ganges do not flow here, nor is there found the rich beauty of Indra's garden, and here there are not the [palaces] that sparkle

\footnotetext{
(Sragdharā)

devah puradhag adhyāste yam abhramikașam uccakaih /

harșakhyātị sa harșākhyo girir eșa punātu vah //9//

(Anuștubh)
}

20 Here I disagree with Bhandarkar's argument for a literal interpretation that there were two shrines. There is no indication of a second, distinct temple in another location on the mountain, nor does the mountain have two distinct peaks. Although the Himalayan abode of Siva is not named explicitly in these verses, his identity as the 'Mountain Lord' was a long-standing topos in his mythology and iconography. 
brightly with jeweled and golden turrets; however, this mountain possess a different, superior [and] unparalleled beauty. For that Śambhu dwells here in visible form is the true source of its delightfulness. [10]

The eight-formed Lord of the eight perfections resides here himself: $[\ldots]$ of the mountain's superior majesty. [11] CECIL $^{21}$

These verses describing the beauty of the mountain itself are followed by a more specific description of the glorious temple of Lord Harsa. While the poet's praise of the monument as being comparable to Mt. Meru employs familiar epigraphic hyperbole, the repeated evocation of sacred geography again functions to underscore the centrality of place. ${ }^{22}$

Glory to this palace of the Lord Harșadeva, with its many true delights! Blessed in its precincts and its most excellent main pavilion, which is resplendent like the golden egg. Charming like the (five) sons of Pāṇụu, its enclosure furnished with a ring of raised structures on its edge. Lovely with the well-crafted bull at its arched entry-looking like the peak of Meru! [12]

CECIL

21 gāmgaṃ no nirjha[rāmbha]ḥ pravahati na śubhā nandanodyānalakṣmịh sadratnasvarṇnaśrngāmalavividharuco naiva __ ${ }^{*}[$ s ta]thāttra / anyām dhatte tathāpi śriyam atiśayinìm eșa śailo 'dvit̄̄yām sākșāc chambhur yad āste tad api hi param kāraṇaṃ ramyatāyāhh//ıo// aștamūrttir yam adhyāste siddhyașțakavibhuḥ svayam/ mahimā bhüdharasyāsya paramạ̣ kopi_U U U//n///

*The reading of 'palaces' is based on Kielhorn's conjecture that the two missing akșaras read saudha.

22 [eta]t svarṇnāṇ̣̂akāmtipravaratamamahāmaṇdapābhogabhadraì

prāmitaprāsādamālāviracitavikațāpāṇduputrābhirāmam*/

meroh șrimgopamānaṁ sughațitavvrșasattoranadvāraramyam

nānāsadbhogayuktami jayati bhagavato harșadevasya [harmmyam] //12//

*The edition reads vikatāa (metri causa). Although the meaning of 'vikata' as enclosure is not attested from other (lexical) sources, it is used again with this meaning, and with short 'a', in Verse 33, which describes the well-crafted enclosure (sughatitavikatam) made for the Harṣa temple by the Pāśupata Allața. I take this to mean the area immediately surrounding the temple (i.e. the pradaksinapatha) along which a series of smaller shrines had been built. Since renovations to the larger courtyard (prängaṇa) are described in Verse 42 , I think there is a distinction to be made between the temple enclosure and the courtyard. 


\subsection{Mt. Harșa as Royal Center}

In addition to praising Śiva as the Lord whose dancing animates and directs the cosmos, ${ }^{23}$ the poet also invoked Śiva as a victorious warrior, whose destruction of Tripura was celebrated by the gods. This reference to Śiva's martial prowess would have been a compelling image for the Cāhamānas, who used the same locale to memorialize the military victories of their own lineage. It is certainly no accident that this inscription also records the first instances of Cāhamāna Simharāja's use of the title 'Supreme King of Kings' (mahārājāadhirāja). ${ }^{24}$ Simharāja is also credited with donating funds for the construction and decoration of a monumental temple to honor his kuladeva, who was the source of the clan's success. The poet tells us in no uncertain terms:

This line of great kings had their virtues augmented through devotion to Śambhu. The Lord Harșa is their tutelary deity [kuladeva]; the lineage has become blessed because of him. [27]

CECIL $^{25}$

In the verses that follow, the poet further describes how the sanctity of Mt. Harșa was amplified by various actors and built interventions, beginning with the Cāhamāna kings. In the language of cultural geographers, the lines evince of the use of the mountain temple as 'cultural capital.' Where here the term 'capital' refers both to money and to monumental sites that, as cultural resources, were manipulated by various elites. ${ }^{26}$ In order to reinforce the connection between the Cāhamāna lineage, the Lord Harșa, and the monument itself, the poet repeatedly identifies the splendor of the lineage with that of the deity; the fame of one enhancing that of the other. This is done

23 pādanyāsāvanunnā namati vasumatì śeșabhogāvalagnā [vā $(b \bar{a})]$ hutkșepaih sa[mam ?]_UUUUUU___U__ rkkacandraih /

bhinnāvastham samastam bhavati hi bhuvanam yasya nțtte pravvrtte sa śrīharșābhidhāno jayati paśupatir ddattaviśvānukaminah //3//

24 This epithet is used in the concluding prose section (Line 34).

25 [mahā] rājāvalī cāsau śambhubhaktigunodayāal śrihharșah kuladevo 'syās tasmäd divyah kulakramah //27//

26 Chris Philo \& Gerry Kearns, "Culture, History, Capital: A Critical Introduction to the Selling of Places," in Selling Places: The City as Cultural Capital Past and Present (Oxford: Pergamon Press, 1993), 1-32. 
first by describing the temple as a manifestation of the fame of the lineage progenitor Gūvaka. ${ }^{27}$

First came the lord of men known as the illustrious Gūvaka, of the Cāhamāna family, who attained preeminence as a hero in the assemblies of the foremost princes of the world, the illustrious Năgas and the rest; whose fame remains on the earth in material form as the excellent temple for Lord Harșa, [which] still endures here today and illumines with great $[\ldots .].[13]$

CECIL

Although the structure would likely have postdated this ruler's time, it is still invoked as a tangible trace of early Cāhamāna sovereignty. The material connection between temple and lineage is again reinforced in Verse $18,{ }^{28}$ which records that Simharāja undertook further improvements to the temple, this time by augmenting the structure with gold.

He affixed gold atop Śiva's dwelling, his own royal splendor materialized, resembling the full moon. [18]

CECIL

It is likely that the verse refers to the gilding of the ceiling of the mahamandapa. These intricately carved ceilings are typically arched or vaulted, so the allusion to a bright and shining full moon makes sense in the context. And since the mahämandapa was a gathering place for devotees and the site of ritual practices it would have been a fitting place for a wealthy patron to display a gift.

\subsection{Pāśupatas and 'Pious People'}

While the inscription emphasizes the Harșagiri as the Cāhamāna cult center, these political elites were only one group that invested in the site. The Harșa inscription served as a medium to communicate different registers of belonging, sodality, and community. The third and fourth sections of the record

\footnotetext{
27 ädyaḥ śrīgūvakākhyāprathitanarapatiś cāhamānānvayo 'bhüt śrimannāgādyalokapravaranrpasabhālabdhavīrapratișțah / yasya śrīharșadeve varabhavanamaȳ bhautalī kïrttimūrttir lloke 'dyāpi sthiraișā pratapati paramaih__U__ $U_{-}$[gai?]://13//

28 haimam āropitam yena śivasya bhavanopari / pūrṇnacandropamam svīyam mūrttam ya [śa] $U$ [pim??]daka[m]//18//

Kielhorn interprets this passage to refer to the installation of a golden dome on top of the temple, which is likened to a physical manifestation of the ruler's yaśas.
} 
commemorate the pious works of religious specialists, mercantile communities, and lay devotees.

After the royal eulogy, the inscription praises the Pāsupata ascetics associated with the temple. In the Harșa record the religious specialists appear autonomous - their activities are not explicitly connected with those of the Cāhamāna rulers, nor do the rulers attempt to bolster their own reputations through association with the Pāsupatas - which could be taken as an indication that they operated within somewhat distinct networks of social control. There is, however, a significant geographic connection. The Pāśupata lineage preceptor, Viśvarūpa, is said to hail from anantagocara, the area near Harșa that the Cāhamānas claimed as their homeland. Another preceptor, Allața, migrated from a village nearby Harșa. Since it is likely that Mt. Harșa's history as a regional religious center predated the construction of the temple, this Pāśupata genealogy could attest to a regional tradition with deep ties to the local topography.

The verses that describe the Pāśupata preceptors included in Viśvarūpa's lineage offer a valuable perspective on the self-styling of these gurus as both adherents of an idealized renunciatory lifestyle while, at the same time, important donors orchestrating the development of the temple complex. ${ }^{29}$

Hailing from the Ananta region, where the hereditary tradition was Lakulīśa's teaching of Pañcārtha, was the revered teacher called 'Omniform' [Viśvarūpa], the learned disciple of 'Powerful Lord' [Uttareśvara], [28]

His student was a learned Pāśupata known as 'Praiseworthy' [Praśasta], the clarity of whose knowledge was resplendent, all taint having been cleansed though his rite of initiation. [29]

29 anantagocare śrimān paṇdita auttareśvarah/ pañcārthalākulāmnāye viśvarūpo bhavad guruh // 28 dīkṣājātamaladhvañsavisphurajñā [nani]rmmalah / praśastākhyo bhavac chișyas tasya pāśupatạ̣ kṛtī// 29 bhā [va]rakto [bha]vat tasya śisyo dvināmatollațah / vārgațikānvayodbhūtasadviprakulasaṃbhavah // 30 harșasyāsannato grāmaḥ prasiddho rānnapallikā / sāmisārikakulāmnāyas tato yasya vini[ rgamah] // 31 allațacchadmanā nandī śivāsannasthitikramah / śrīharșāāādhane nūnam svayam marttyam avātarat // 32 // āsin naiștakarūpo yo dīptapāśupatavratah/ tī[ vra] vegatapojātapunyāpunyamalakșayah // 35 sadā śivasamākāras tasyeśvarasamadyuteh / bhāvadyoto bhavac chișyah saṃdīpitagu[rukra]mah // ${ }_{3} 6$ 
His student was 'Impassioned by Bhāva' [Bhāvarakta], whose nickname [dvinäma] was Allața, born in a family of proper brahmins arisen from the Vārgatika lineage. He migrated from the celebrated village of Rānapallikā, located nearby [āsanna $]$ Mt. Harșa, where the hereditary tradition addressed 'worldy' [sāmsārika] concerns. [30 \& 31]

In the guise of Allata, surely Nandin, who keeps himself nearby [äsanna] Siva, has assumed a human form in service to Lord Harșa. [32]

He [Allața], who shared in the lustre of the Lord, had a student called 'Brilliance of Bhāva' [Bhāvadyota], a life-long celibate who is illuminated through his Pāśupata practice [vrata], part of a succession of luminous teachers, always like Śiva, he effected the destruction of the taint of both virtue and vice through the vehement intensity of his asceticism. [35\& 36 ] CECIL

In addition to the localization of the lineage, the description of Viśvarūpa includes an important description of the doctrine connected to this region as that of Lakulīśa's teaching of Pañcārtha. This detail is particularly significant for this study since 'Pañcārtha' is the same term used to describe the Pāśupata doctrine expounded by Lakulissa in the SP. ${ }^{30}$ The doctrine of the others in the lineage is not explicitly called Pañcārtha, but the preceptors are clearly identified as Pāśupatas. In Viśvarūpa's lineage, comes Praśasta, who is not connected with a specific doctrine or lineage. He is described as a Pâsupata who has undergone initiation $(d \bar{\imath} k s \underline{a}) .{ }^{31}$ Allața's student Bhāvadyota, is described as being engaged in the Pāśupata practice (vrata), which could lend another, literal, interpretation to his being 'illuminated' by reference to a body that appears white or glowing due to its being smeared with ash.

With the introduction of Praśasta's student Bhāvarakta (a.k.a. Allața) in Verse 30 , the poet begins to describe the religious specialists who were involved directly in the building and renovations of the Harsa temple. The description of Allața contains important and intriguing details. The first concerns his name(s). The first name given is Bhāvarakta, a name with the bhāvaprefix common amongst Pāśupatas. ${ }^{32}$ Although this 'official' name was the one that signaled his Pāsupata identity, subsequent mentions of him in the record use his second name, Allața. This appellation has no meaning in Sanskrit, but

30 And Pañcārtha is the same name given to the teaching by Kaundinya in his Pañcārthabhāṣya on the Pāśupatasūtra as well. See Chapter 1.

31 Verse 29.

32 Cf. Dominic Goodall, "On K. 1049, A Tenth-Century Cave-Inscription from Battambang, and on the Sectarian Obedience of the Śaiva Ascetics of Non-Royal Cave-Inscriptions in Cambodia," UDAYA, Journal of Khmer Studies 13 (2015): 3-34 (26-28). 
it must have had a specific resonance in the local language that made it important enough to warrant inclusion in the Sanskrit inscription. It is also significant that the reference to his second 'nickname' (dvinama) employs the same language and notion of doubling used earlier to describe Śiva's localized manifestation on Mt. Harșa. Allata's initiation name offers him legitimation via his ties to a respected lineage, but like Śiva's particular manifestation as Harșa, it is his local appellation that is given greater weight. Allața's identity as a local is also emphasized through spatial metaphors. In Verse $3^{1}$ his hometown is described as being nearby (äsanna) Harșa. The same term for nearness is repeated in the following verse to express an emotional affinity and dedication to the Lord.

The description of Allața's hereditary or lineage doctrine sets him apart from the other preceptors eulogized in the inscription. Given that he is included in the line of Viśvarūpa, we may infer that Allața, too, was initiated in Lakulīśa's teaching of Pañcārtha. Along with the inclusion of his second name, Verse 31 mentions a second doctrine specific to the village of Rānapallikā, called the sāmsārika tradition. The nature of this doctrine is obscure, although it must have been considered a detail essential to Allața's identity. There are two primary ways in which we can interpret the name of this 'worldly' doctrine. On the one hand, it could refer to teachings that help the aspirant to escape samsāra and the impediments to spiritual liberation that attend attachment to the mundane world. A second option would be to interpret samsāra in a more neutral way, as referring simply to mundane or worldly concerns. Allața's village may have been celebrated because it was home to brahmin ritual specialists who were skilled in the performance of rituals that addressed the community's quotidian needs-i.e. concerns for health, fertility, and prosperity. Much like some of the early examples of Pāśupata religious specialists integrated within temple-centered communities, ${ }^{33}$ the gurus in residence at Harșa likely performed a variety of ritual functions, some of which would have involved non-Śaiva deities. Indeed, their own donations allude to broader concerns for the overall ambiance of the site and general well-being of the community. Read in a broader social context, the mention of the sāmsārika tradition designated Allața as a religious specialist who was skilled and attuned to the needs of a wider lay community outside of the initiated elite within his prestigious lineage.

The inscription reveals the ways in which these religious specialists, who are described as free of attachments to material and worldly concerns, reconcile their ascetic values with their investments in the monumental landscape of

These inscriptions are discussed in Chapter 1. 
Mt. Harșa. The poet begins with Allața. While the Cāhamāna rulers are credited with significant donations to Lord Harșa, it was the Pāśupata teacher Allaṭa who reportedly commissioned the temple using funds obtained from pious donations. After his death, Bhāvadyota followed his teacher's command to continue work on the temple by making further improvements to the grounds: including a courtyard, garden, well, and stone cistern to provide water for cattle. ${ }^{34}$ These details hint at a kind of qualitative division of 'donative labor.' Whereas the connection of the rulers to the temple was primarily through monetary donations or gifts of land, the specific constructions undertaken by the religious specialists are recounted in detail. The following two verses describe Allața.

A celibate student from birth, clad in nothing but the spotless sky, an ascetic with his spirit controlled, he had taken birth [as] a friend to those whose minds are set upon traversing samsāra [...] he had abandoned the delusion of worldly existence [and] his resplendent mind was occupied solely with service to Lord Harșa. He commissioned this palace for [Śiva as] Harșa, with its well-executed complex, using funds from pious donors. [33]

Upon seeing the unrivaled temple of Paśupati, celebrated by the name Lord Harșa, that he commissioned on this mountain of the moon-marked god that licks that path of the stars with its peak-[the temple that] resembles a celestial palace, the abode of numerous deities, furnished with every enjoyment-clearly there is nothing that cannot be obtained through their asceticism for ascetics who are without desire. [34]

CECIL $^{35}$

These two verses perfectly juxtapose the life of the ascetic, who is free of possessions and attachments to mundane world, with a monumental palace to the Lord, in which no expense has been spared. Although these images may appear to be incongruent at first, Verses 33 and 34 make clear that commissioning

\footnotetext{
34 Verses $37-39$ \& 42.

35 ājanmabrahmacārī digamalavasanaḥ saṃyatātmā tapasvī śrīharșārādhanaikaryasanaśubhamatis tyaktasaṃsāramohah I

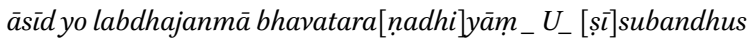
tenedạ̣ dharmavittaị sughațitavikațạ̣ kāritạ̣ harșaharmmyam // 33 // asmiṃś candrāṃkaśaile gaganapathalihottungaśrñge 'prameyam harmmyaṃ śrīharșanāmaprathitapaśupateḥ sadvimāno[pa]mānam/ drșțā sadbhogayuktam bahusurabhavanam kāritam yena nāsādhyam kiṃcid asti sphuțam iti tapaso niḥsphṛhānāạm yatīnām //34
} 
the temple was not an act of personal promotion on the part of the Pāśupatas; rather, it was done out of their desire to be of service to and honor the Lord. The poet also explains that the support for the monument came from pious donations, thus mitigating speculation that the resources came from the ascetics' personal resources. It is this unselfish action that made the astonishing monument possible. The verses below commemorate Bhāvadyota's contribution in a similar rhetorical style. The image of the ascetic without any possessions to tie him to the world provides a stark contrast to the sense of permanence of the heavy stones that surround the temple.

These were his 'possessions': the sky for clothes, a mass of matted hair, ashes, the earth as his broad bed, alms for food, and his hand as a cup. [41]

After he had filled completely that deep [...] which was [...] of Siva's temple with a heap of rocks, he commissioned a beautiful courtyard paved with smooth stones that gave it a level surface pleasant for walking [42]

CECIL $^{36}$

We learn more about the donative patterns at Harșa in the inscription's concluding section, which memorializes gifts received before VS 1030/973 CE. The summary list begins with villages ${ }^{37}$ donated by the Cāhamāna kings and their officers. Following these royal dispensations, donations made by two different merchant groups are mentioned. The first are dealers in salt from Śākambharī who agreed to donate one vimśsopaka on every measure (kütaka) of salt that they sold. ${ }^{38}$ In addition, horse traders 'from the north' (uttaräpatha) agree to contribute one drama on every horse. ${ }^{39}$ Although the reference to the provenance of the horse dealers is vague, a contemporaneous inscription from Pehowa records comparable acts of tithing by a confederation of horse traders coming

${ }_{3} 6$ digaṃbaramjațā bhasma talpam ca vipulam mahī/

bhikṣā vṛttih karah pāttram yasyaitāni parigrahah // 41 //

śivabhavanapu _- $U[$ pā] ram yad àsìt tad akhilam upalaughaị pūrayitvā gabhīram /

samatalasukhagamyam prānganam tena kāntam mașrnataraśilābhị kāritaṃ bandhayitvā //42//

37 Some of these villages end with the suffix -kūpaka/kūpa that likely refers to a well (Line 38). Another ending in -lāvanapadra could indicate a place of salt production or salt trade (Line 40).

38 The title given for this collective is samastaśrībhammahadeśya (Line 38).

39 These horse merchants called hedāvikas (variant hețāvuka) are known from other epigraphic sources. C. Gupta, "Horse Trade in Northern India: Some Reflections on SocioEconomic Life," Journal of Ancient Indian History (1983-4): 86-206. 
from various locales. ${ }^{40}$ Despite these very terse descriptions, the mention of these two high-profile trading networks suggests that the Harșa temple had attained sufficient renown to solicit patronage from local and supra-local groups at a prominent site at the junction of trade routes. It is likely that the sheer size of the mountain would have contributed to its importance as a regionally important landmark and point of convergence for traders and travelers. ${ }^{41}$

The donative charter concludes with gifts by unnamed individuals, presumably persons without a specific social rank. The donations of 'fields for the enjoyment of the god' by these 'pious people' (punyātmabhir dattāni devabhujyamānakșettrāni) is further evidence for an established pattern of lay patronage at Mt. Harșa. ${ }^{42}$ We might infer the same from the names of the craftsmen mentioned in the inscription-Canḍaśiva and his father Vīrabhadrawhose names indicate a preference for Siva. The donors are anonymous, but the fact that these gifts are mentioned alongside those of the ruling family indicates that they were deemed significant enough to feature in the public record.

Materializing Śaivism on the 'Mountain of Joy'

The inscription from the Harșagiri commemorates publicly the enduring ties between royal power, Pāśupata identity, and various other local and supralocal groups through the common idiom of Śiva devotion. But these acts of commemoration were not restricted solely to linguistic or textual expressions. The temples, monuments, and images that populate the site serve a corroborative function. They are the material traces of these collaborative expressions of

40 G. Bühler, "The Peheva Inscription from the Temple of Garībnāth," EI 1 (1889-92): 184-190. An inscription from Kiradu (1161 CE) in northwest Rajasthan mentions horse trade: B.N. Reu, "Kirādu Inscription of the Time of Chaulukya Kumārapāla and his Feudatory Paramāra Someshvara dated V.S. 1218," IA 61 (1932): 135-136.

41 Although I cannot confirm this, in his description of the site Dean claims that the mountain, and even the face with the temple, is visible from as far as Jaipur. As described in his report: "On arriving at the building which had principally excited my curiosity from the plain below, I found it occupied a site about quarter distant from the southwesterly end of the top of the hill, and on the precipitous verge of the northern face. The guide and officiating brahmans informed me, that it may be distinctly seen from the hills round Jaipur, thirty-five coss S.E. from Sambhar, thirty coss south of Midag, and when standing in relief against the dark background of a rainbow, it has frequently been seen from thence and Baudra, two villages or towns in the said territory, distant forty-five coss N.E. by E. Such is the native account, which I think is entitled to belief, as I have myself seen it from Taen, a distance of about forty miles, at least I imagine so, without taking much trouble to find it out." (Dean, "Ruins of an Ancient Temple at Harsha," 168). 
piety. The remains from Mt. Harṣa are particularly important because they afford us the relatively rare opportunity, in premodern North India, to integrate the literary and material constructions of a landscape.

According to the earliest reports, the inscribed stone was found in the rubble surrounding the remains of a massive medieval temple. Since the epigraph credits the Cāhamāna ruler, Simharāja, with renovating a monumental temple to honor his family's lineage deity, today this shrine is regarded as the old Cāhamāna temple, the same structure referred to in the inscription. This central temple has been extensively rebuilt and renovated over time. In its current state, this temple enshrines what may be a medieval caturmukha linga; although a second shrine, directly behind the rebuilt temple, also preserves an early linga. As described in the inscription, smaller shrines within the courtyard surround the central temple. The remains of a mandapa with a massive carved bull sitting at the entrance also echo the descriptions of the Cāhamāna temple given in Verse 12 of the inscription [Figures 38 \& 39]. ${ }^{43}$

The atmosphere of joy and celebration evoked by the name of the mountain and its tutelary deity is materialized in the iconography from the site itself, examples of which are preserved within the complex and in the Government Museum in Sikar. Depictions of joyful devotion, dance, and music provide one of the dominant themes of the iconographic program. Images of a dancing Śiva also appear as a repeated iconographic topos and materialize the vision of Siva recorded in the inscription [Figure 40]. In addition to the many sculpted panels of dance and devotion, repeated scenes depicting different kinds of people worshipping the linga gesture to the multivocality of the larger māheśvara community that used the space. For example, the numerous small, sculpted panels that adorn the rows of pillars within the central hall of the main temple include scenes of linga worship in which ascetics and gurus as well as members of a broader laukika community comprised of both men and women are depicted together engaged in the quintessential Śaiva practice of linga püja [Figure 41]. While these images are not works of art on a par with some of the other sculptures at the site, their position within the communal space of the central temple would have made them highly visible representations of the community.

Though the māheśvara community was clearly diverse, specific emblems of the Pāsupata community also figure prominently in the many images of Lakulīsa, the tradition's founding teacher. These icons consistently show Lakulīśa with multiple arms, wielding the club and other familiar Śaiva attributes (triśüla, nāga, etc.). Since the temple complex is still an active devotional 


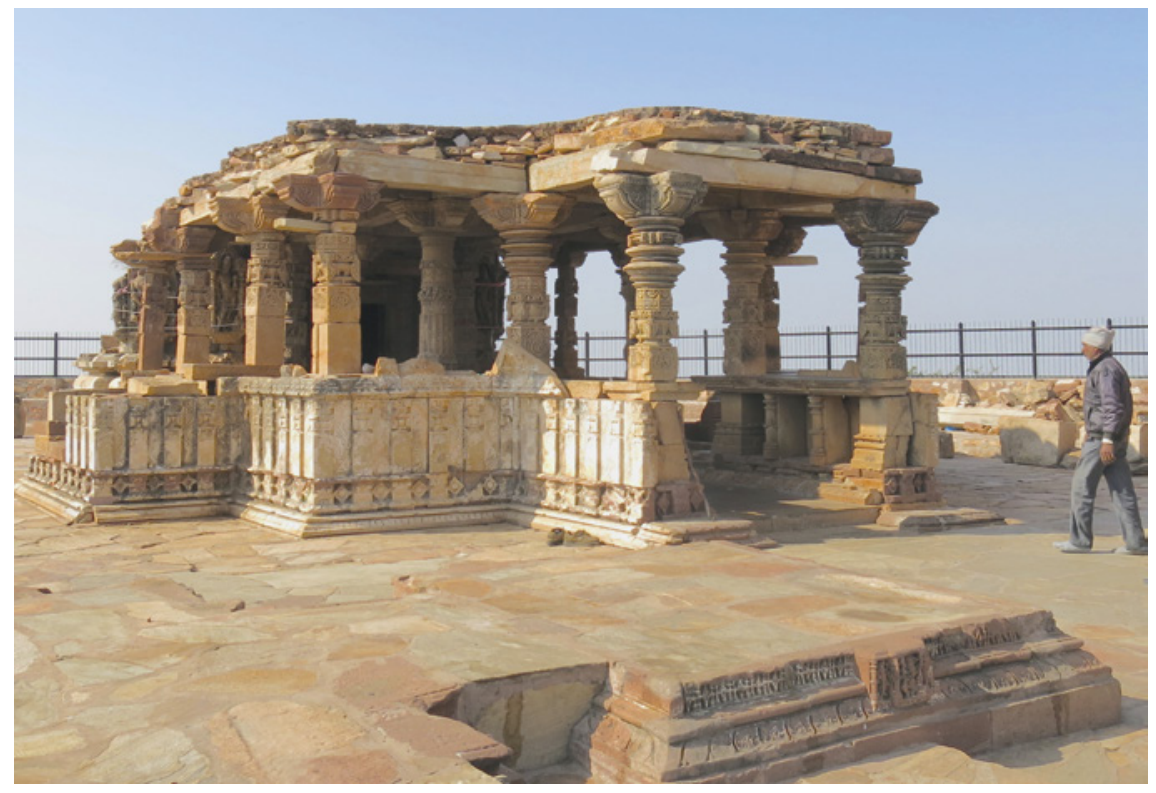

FIGURE 38A Remains of c. 1oth century temple complex on Mt. Harṣa

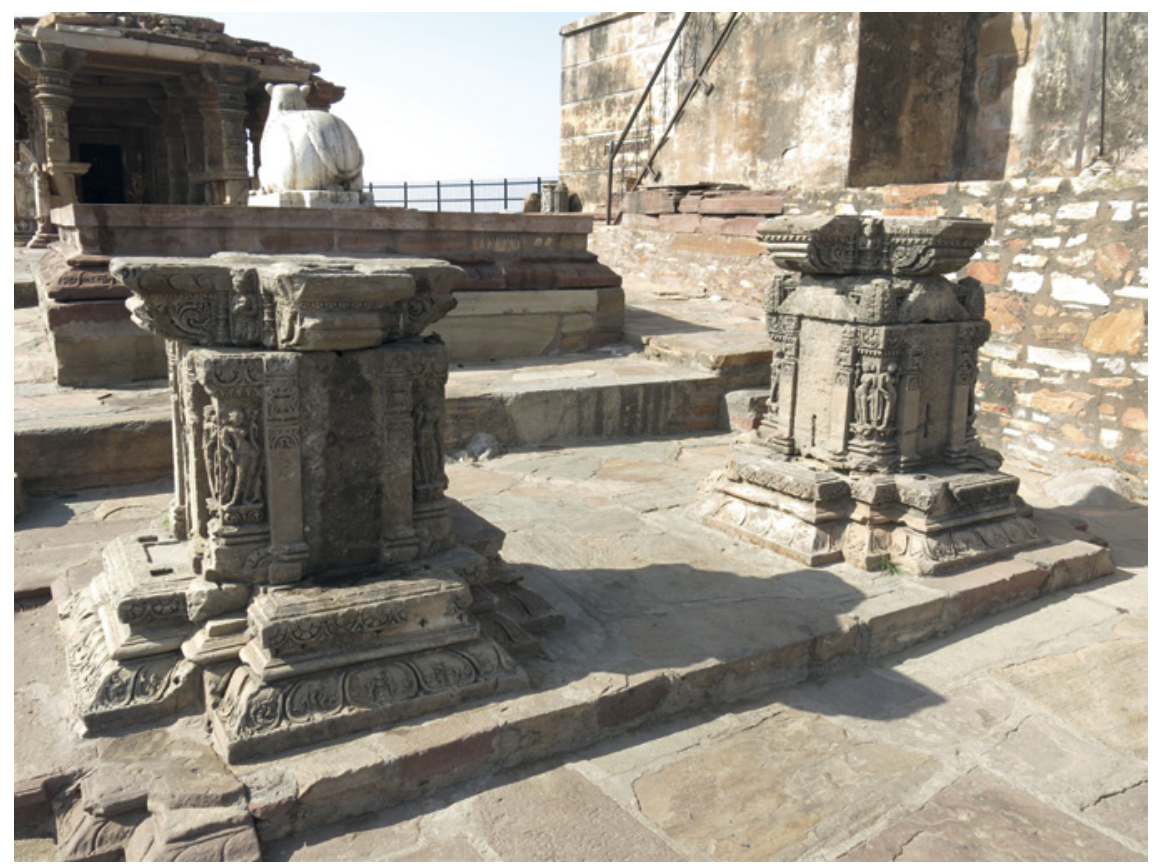

FIGURE 38B Bull in courtyard, Harșa Temple complex, c. 1oth century 


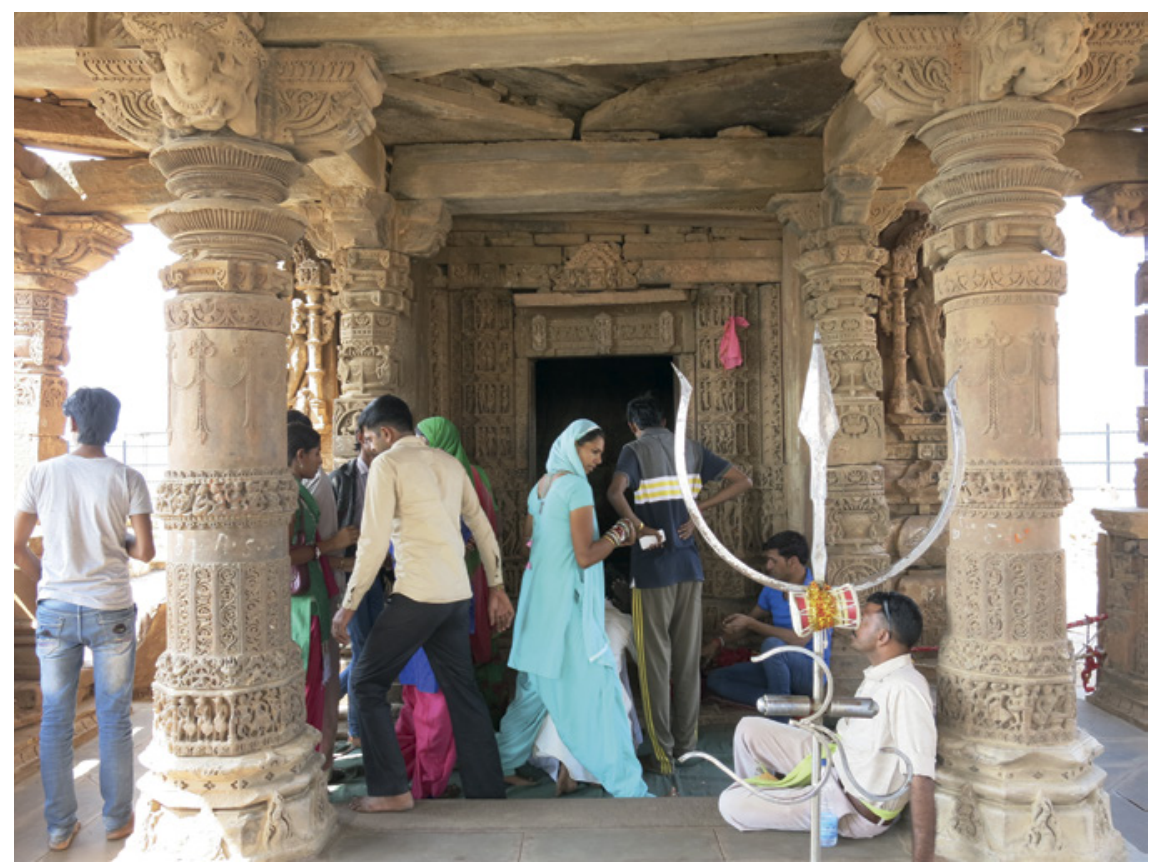

FIGURE 39A Entry to temple sanctum, Harșa Temple, c. 1oth century

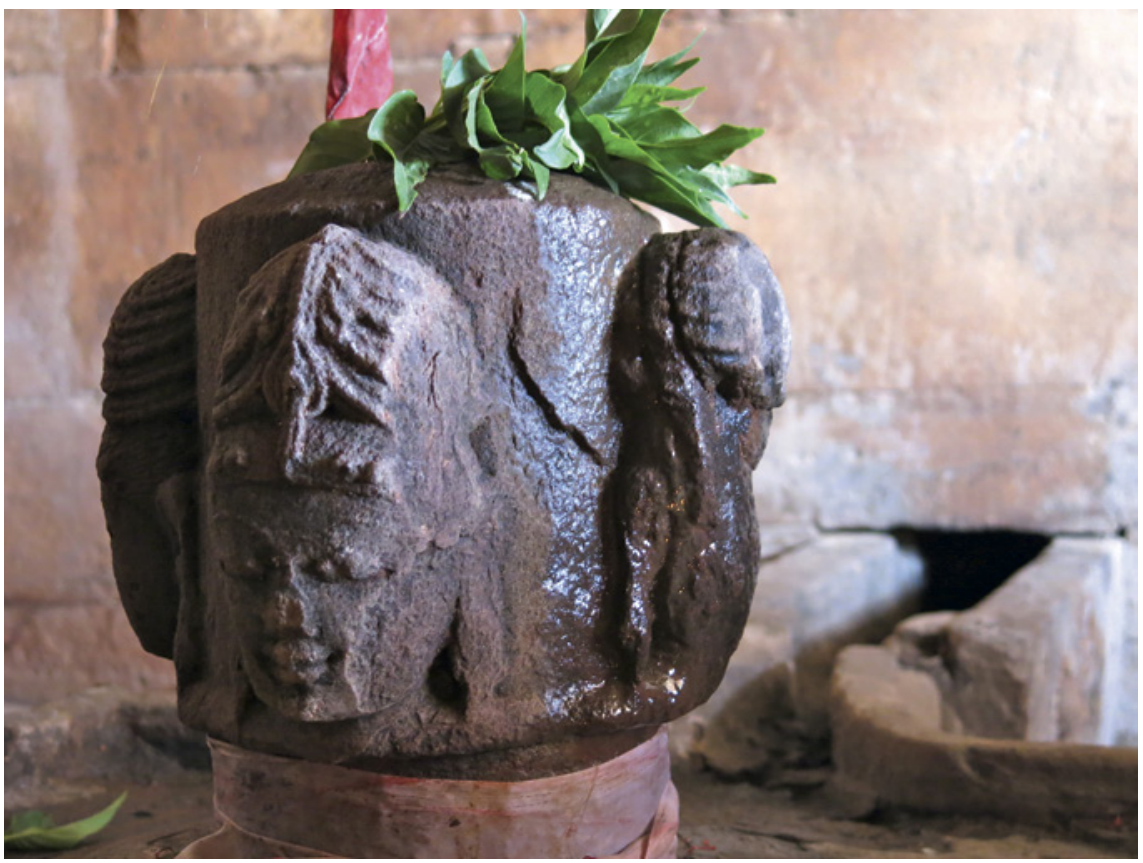

FIGURE 39B Interior linga shrine, Harșa Temple, c. 1oth century 


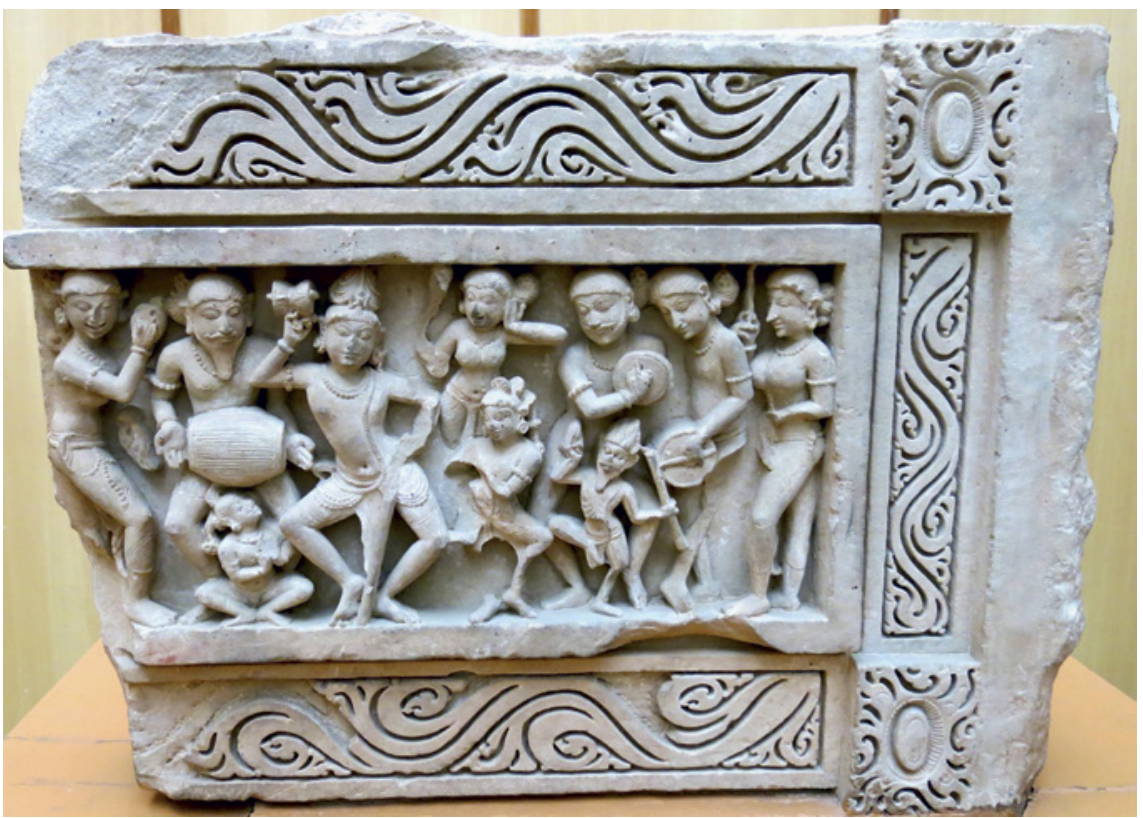

FIGURE 40 Dancing, two-armed Śiva from Mt. Harșa, c. 9th-1oth century SIKAR GOVERNMENT MUSEUM

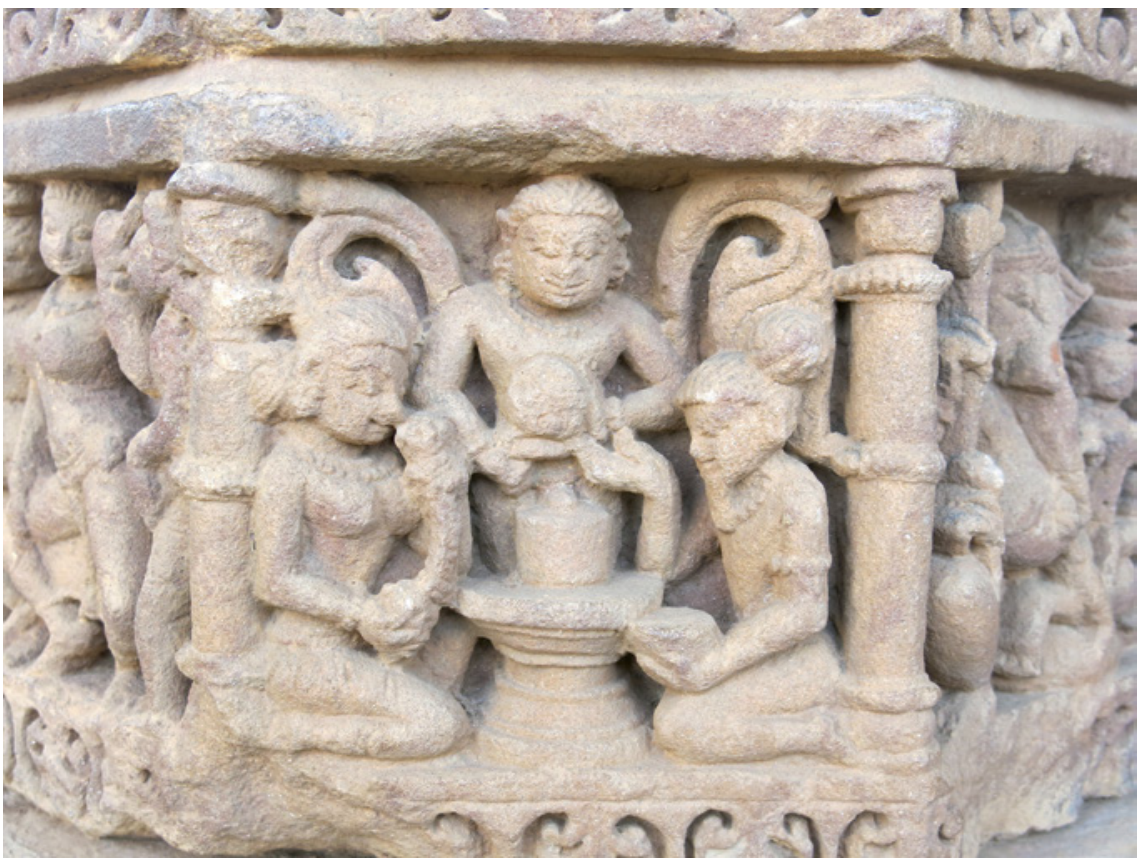

FIGURE 41 Panel depicting linga veneration, Harșa Temple, c. 1oth century. See also Chapter 5, Figure 103, pp. 238-239 


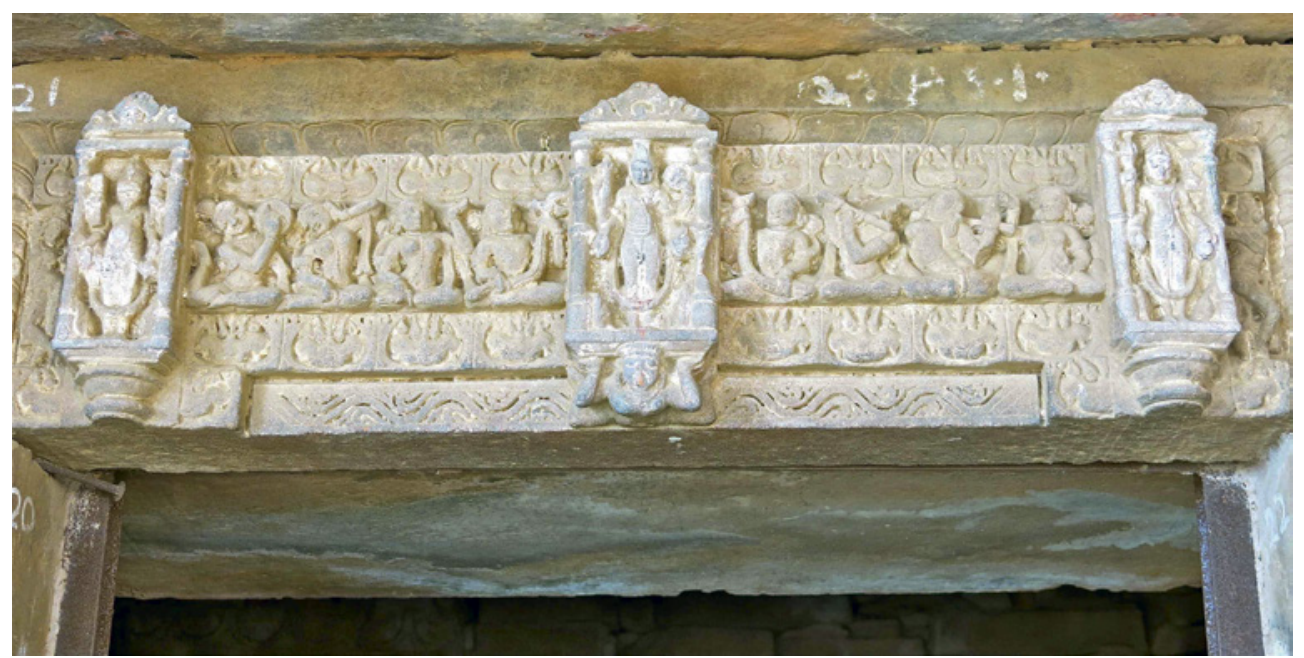

FIGURE 42

Repurposed lintel with central Viṣnu image, Harșa Temple, c. 9th-1oth century

space, many of the structures have undergone significant renovations and rebuilding. This is evident, for example, in the lintel of the main linga shrine. The temple is still under active worship as a Siva temple, but as a result of ongoing renovations and repairs, a portion of a Viṣnu temple has been repurposed within the Siva shrine. Given that this temple was originally a Śaiva dedication, an image of Śiva or one of his manifestations should appear in the central niche of the lintel. Yet, it is Viṣnu who now occupies this prominent place. Based upon the dimensions of the doorframe, I think the broken lintel preserved within the temple courtyard, in which Lakulissa appears in the central niche, would have originally appeared in the doorframe above the central linga shrine to signal its Pāśupata affiliation. [Figures 42 \& 43]

\section{1 'Śaiva' Place as Lived Space}

Given that the rhetorical aim of the Mt. Harșa inscription was to praise the Cāhamāna's temple and homologize the mountain with Śiva, the poet does not explicitly mention the worship of other deities within the sanctified space. This preference on the part of the rulers and religious specialists does not imply, however, that Siva was the only deity enshrined on the Harsagiri. The temple dedicated to the Cāhamāna kuladeva was one of many in the extensive complex and the material record preserves evidence of Śaivism alongside a broader and dispersed set of religious practices and concerns. During my fieldwork, I noted the remains of at least twelve temple foundations 


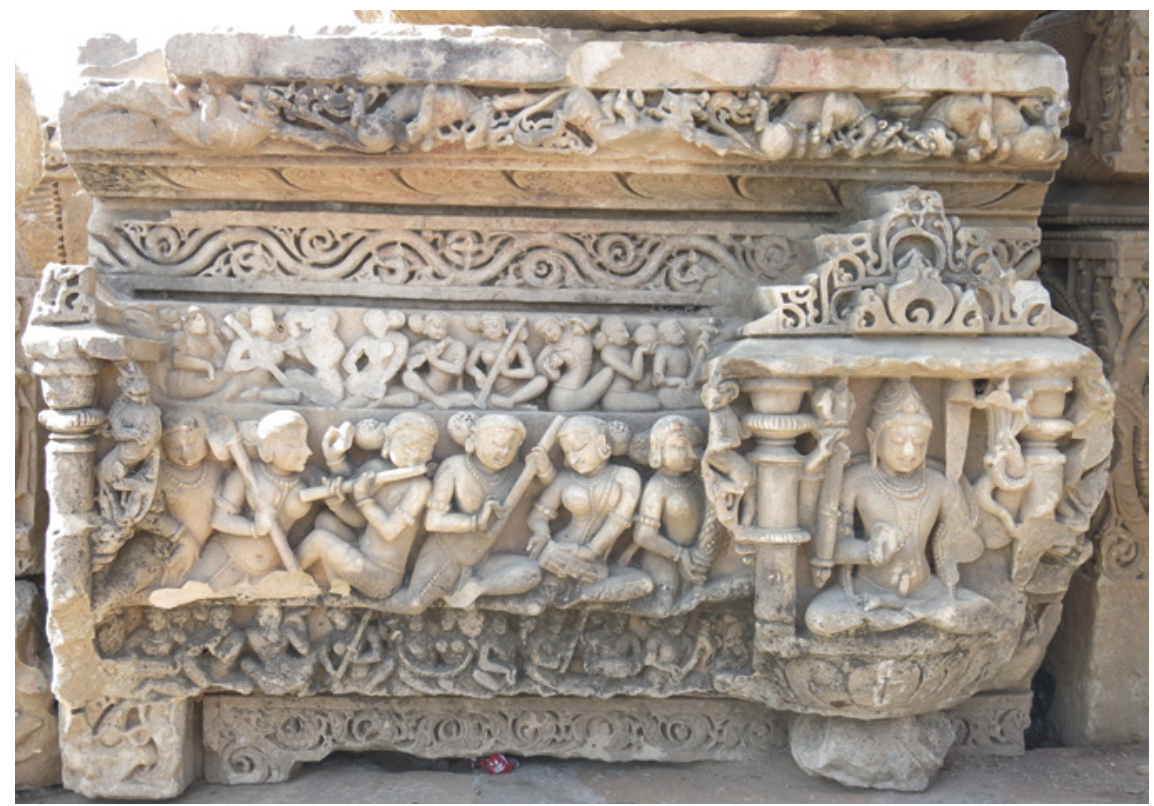

FIGURE 43 Original lintel with Lakulisśa, loose sculpture at Harṣa Temple complex, c. $9^{\text {th-1oth century }}$

(c. 9th to 11 th century). ${ }^{44}$ Some of these foundations are significantly smaller and simpler than the Cāhamāna shrine, which could indicate that they were dedications by non-royal donors and serve as further evidence for the wide range of social participation on this sacred mountain - that is, to its life as a lived space. In this way, the built landscape similarly reinforces the investment of these various groups in participating and celebrating the sanctity of Lord Śiva's abode. ${ }^{45}$ The presence of these other temples is a clear indication that religious hierarchy and authority were not expressed through strategies of exclusion. The dispersion of temples and images attests to a richly varied and complex religious center, one that would have accommodated a range of ritual

44 EITA editors also note the smaller shrines, which they take to be roughly contemporaneous with the main temple. They also confirm that the uneven arrangement and size of the smaller sub-shrines shrines means it was not originally conceived as a pañcāyatana complex. EITA 2.3, 107 .

45 Given the richness of the sources, continued effort is needed to map patterns in the iconographic program across the site, to identify communities using the spaces, and to explore the relationships between the various structures that comprise the complex. I began this process during my fieldwork and published my findings in 2017. See Elizabeth A. Cecil, "The Medieval Temple as Material Archive: Historical Preservation and the Production of Knowledge at Mt. Harșa," Archive Journal (2017) http://www.archivejournal.net/essays /the-medieval-temple-as-material-archive/. 


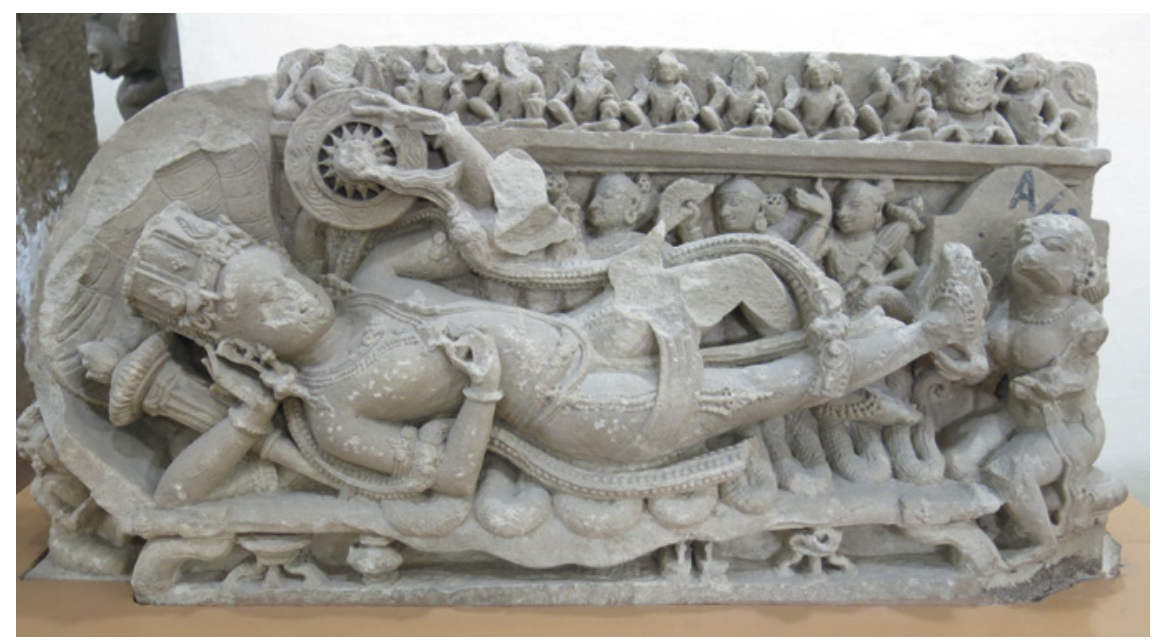

FIGURE 44

Viṣṇu Śeșaśāyī from Mt. Harṣa, c. 9th-1oth century

SIKAR GOVERNMENT MUSEUM

concerns and practices. Since this multivocality is not given expression in the epigraphic record, it is only through analysis of the structures and sculptures on site that these voices may be heard.

Judging from iconographic remains, some of the smaller temple foundations mentioned above would have been dedicated to Viṣnu, one of the major deities of the Hindu pantheon and Śiva's primary competitor. During my fieldwork, I identified three displaced temple lintels deposited within courtyards at the site in which Viṣnu - easily recognized by his signature attributes of club ( $g a d \bar{a})$ and discus (cakra) — appears as the central deity. One of these was also repurposed in the Harșanātha linga shrine as noted above. His central position is a strong indication that the shrines these lintels framed were dedicated to Viṣnu. While the ruling elites aligned themselves closely with Siva, the smaller Vaisnava structures attest to the broad-based support of other cults within the shared space of the temple complex. Small icons depicting specific manifestations (avatäras) of Viṣnu have been repurposed throughout the site. In addition to these, large sculptures of Viṣnu in his Śeșaśāyī, Gajendramokṣa, and Vaikunțha forms are preserved in the Sikar Museum [Figure 44]. The presence of these images is significant since they attest to the activities of artisans and donors with a detailed knowledge of Vaiṣnava mythology and theology.

Along with Viṣnu, the Sun god, Sūrya, is also represented prominently at the site. Based upon the range and scale of the images collected within the complex, it is likely that there were also temples for this deity on the mountain. One of the on-site storage sheds also contains a rare image of Chāyā, one of Sūrya's 


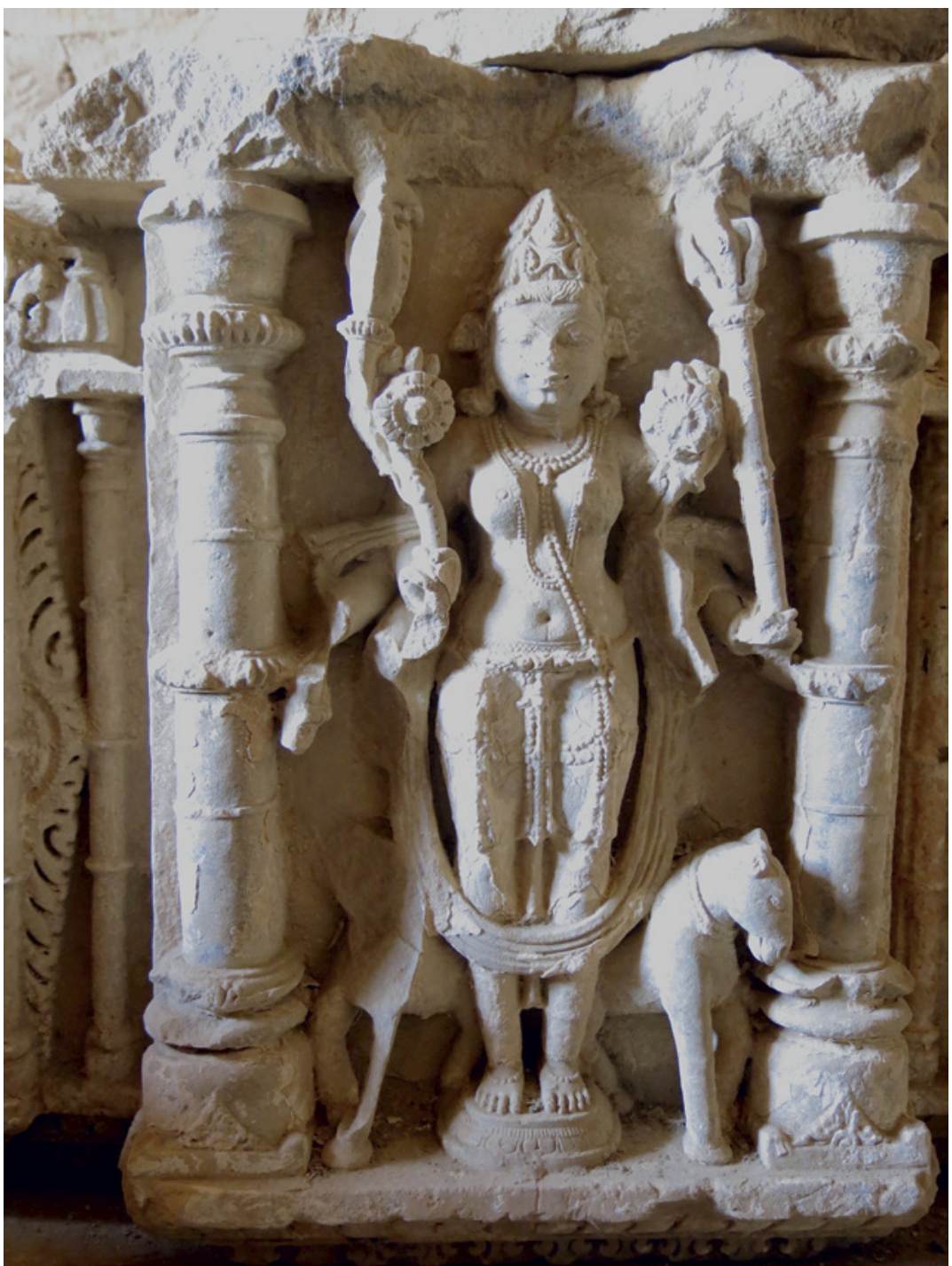

FIGURE 45

Chāyā, wife of Sūrya, Harșa Temple complex storeroom,

c. 9th-1oth century

wives [Figure 45]. Chāyā's iconography bears a strong resemblance to that of her husband. She is depicted holding a lotus flower in each hand. The horses that draw the chariot of the Sun are shown at her feet. In addition to these attributes that convey her association with Sūrya, Chāyā also holds a trident in one of her left hands. As Śiva's signature weapon, the inclusion of the trident expresses a visual link between Chāyā and Śiva. The intervisibility of Śiva and Sūrya in early medieval Rajasthan marks a significant regional pattern, 
and the remains at Harșa are but one example of the prominent trend. ${ }^{46}$ The Sikar museum collection includes icons that blend key iconographic features of these deities to produce composite forms. When seen as objects from a coherent collection, the Chāyā icon, composite images, and the Sūrya sculptures repurposed in the temple complex provide a clear indication that Mt. Harșa was a regionally prominent center for the Sun cult.

\subsection{Siva and the Goddess(es)}

Having considered the inclusion of competing religious cults within the Harșa complex, there are also many deities traditionally included within the Śaiva pantheon that occupied important places within the site. The most prominent and widely worshipped of these was the Goddess in her various manifestations: as Śiva's wife Pārvatī, the demon-slaying Durgā, the fearsome Cāmuṇụā, with her necklace of skulls, as well as Ardhanāriśvara, a representation of the union of Śiva and Pārvatī, popular in the region. ${ }^{47}$ The artists of the Salt Lakes region were particularly fond of scenes depicting Pārvatî's acts of asceticism [Figure 46] These icons were popular at Mt. Harșa and also at an 8th century shrine located just adjacent to the Dịdvānā Salt Lake. This goddess temple has been extensively rebuilt, but within its narrative panels are preserved scenes of Pārvatî’s austerities and subsequent transformation on Gaurīsikhara. ${ }^{48}$

In addition to the Goddess par excellence as embodied in Pārvatī, Harșa's sanctified spaces abound in representations of the various subordinate, yet still powerful, goddesses sometimes associated with her, i.e. Mātrkās (Mother goddesses) and yoginis. [Figures $47 \& 48]$. These ambivalent goddesses were seen as sources of power that were worshipped by religious adepts and connected with fertility cults, invoked for the protection of expectant mothers and young children. At present, nearly all the images of these goddesses are rebuilt in walls and under worship in small shrines within a circular openroofed structure on the eastern end of the complex [Figure 49]. The original purpose and date of the structure are impossible to determine; its architectural layers preserve numerous historical moments and building phases. Yet, it is significant to note that the building recalls the structure of early yogin $\bar{\imath}$ shrines, which typically enshrined sixty-four goddesses in a circular temple that was open to the sky. Ritual activity at this place today is centered on an underground temple to Bhairava, a particularly fearsome manifestation of Śiva who is propitiated by couples to ensure the protection of their children. It is

\footnotetext{
46 The remains from Kāman and Satwas evince a similar affinity (see discussion below).

47 On the popularity of this form see also Chapter 2.

48 See Michael W. Meister, "Gaurīśikhara: Temple as an Ocean of Story," Artibus Asiae 69.2 (2009): 295-315; Yokochi, "Introduction," SP III.
} 


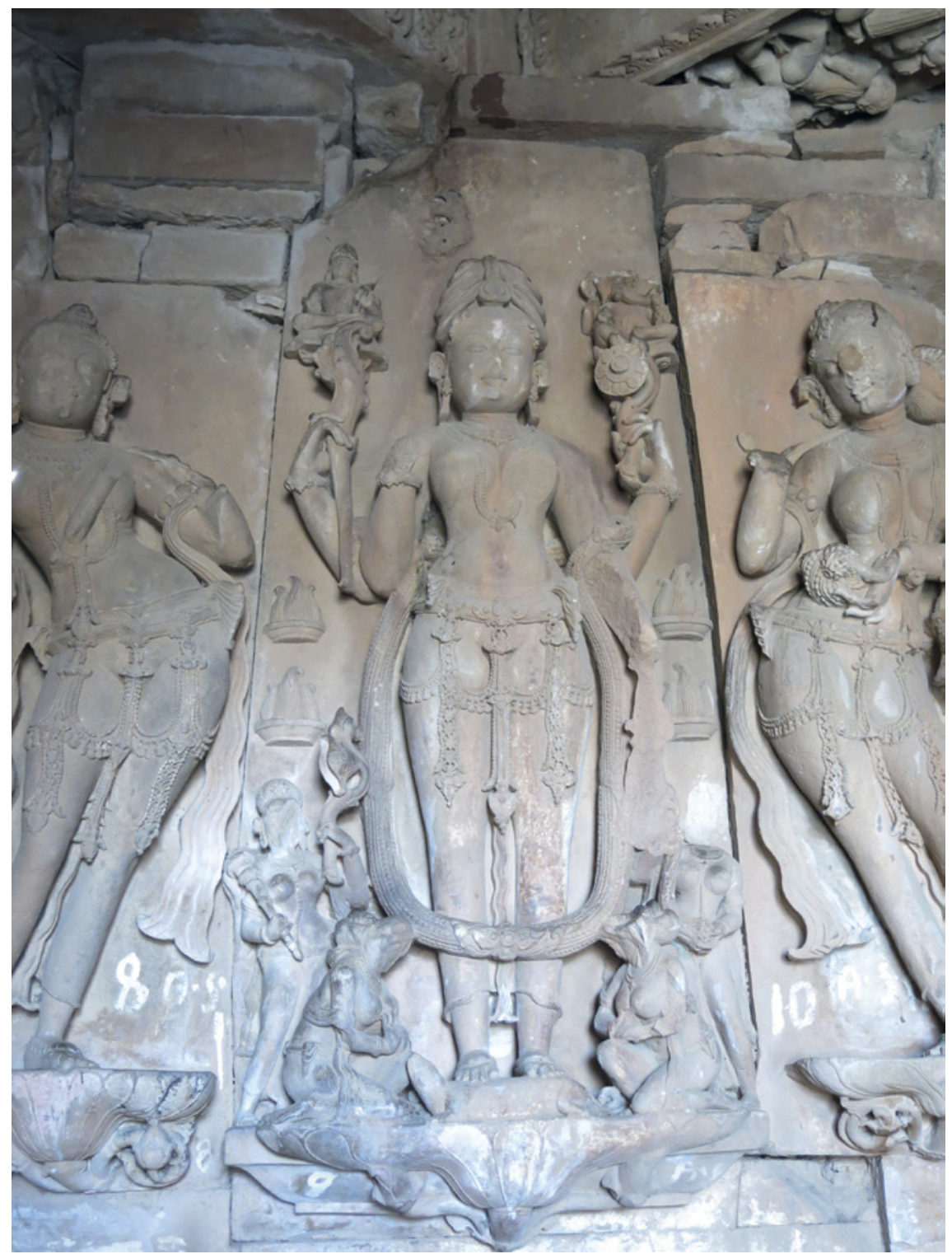

FIGURE 46 Repurposed sculpture depicting Pārvatī undertaking pañcāgnitapas, interior of Harșa Temple, c. 9th-1oth century 


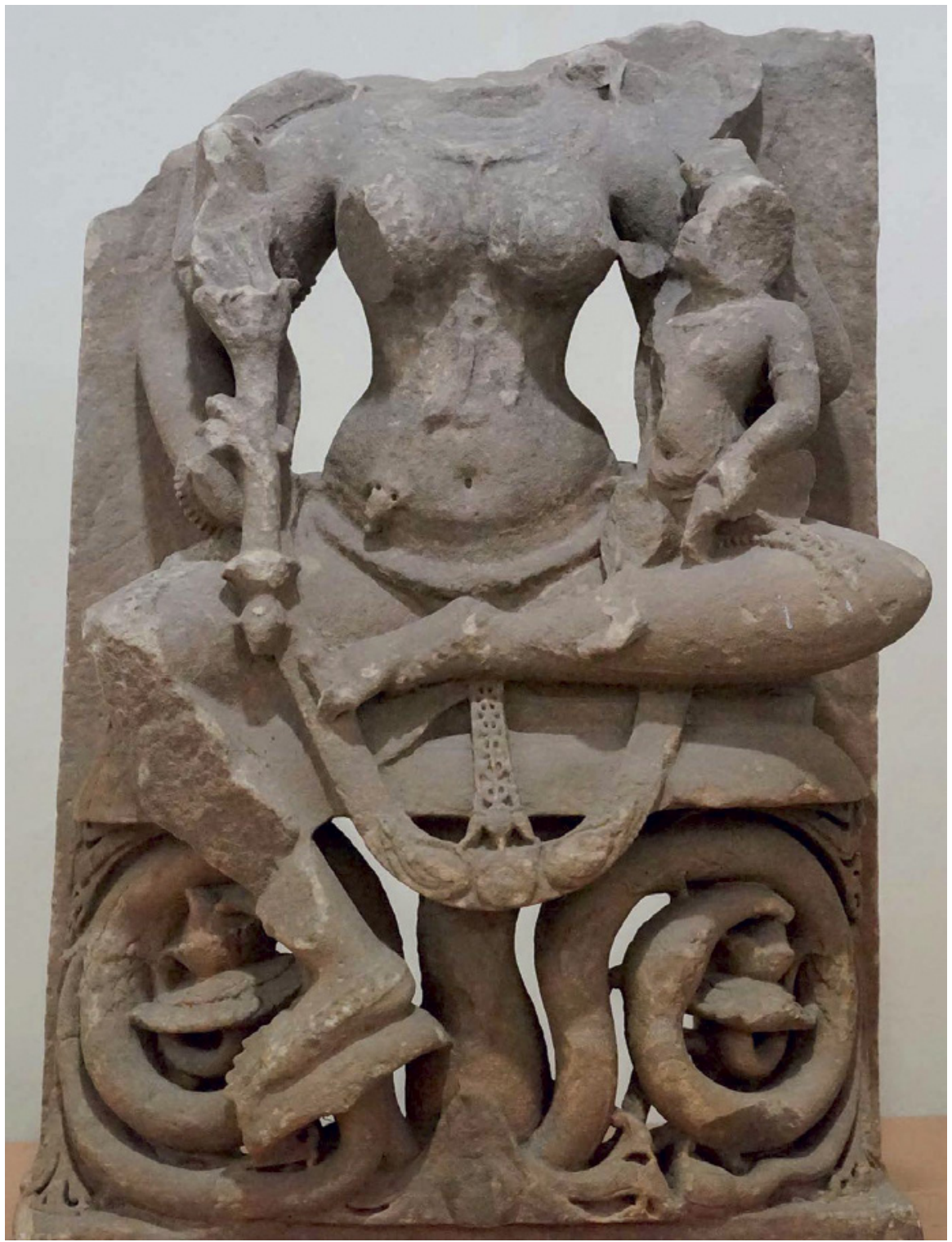

FIGURE 47 Mātrkā sculpture from Harṣa Temple complex, c. gth-1oth century SIKAR GOVERNMENT MUSEUM 


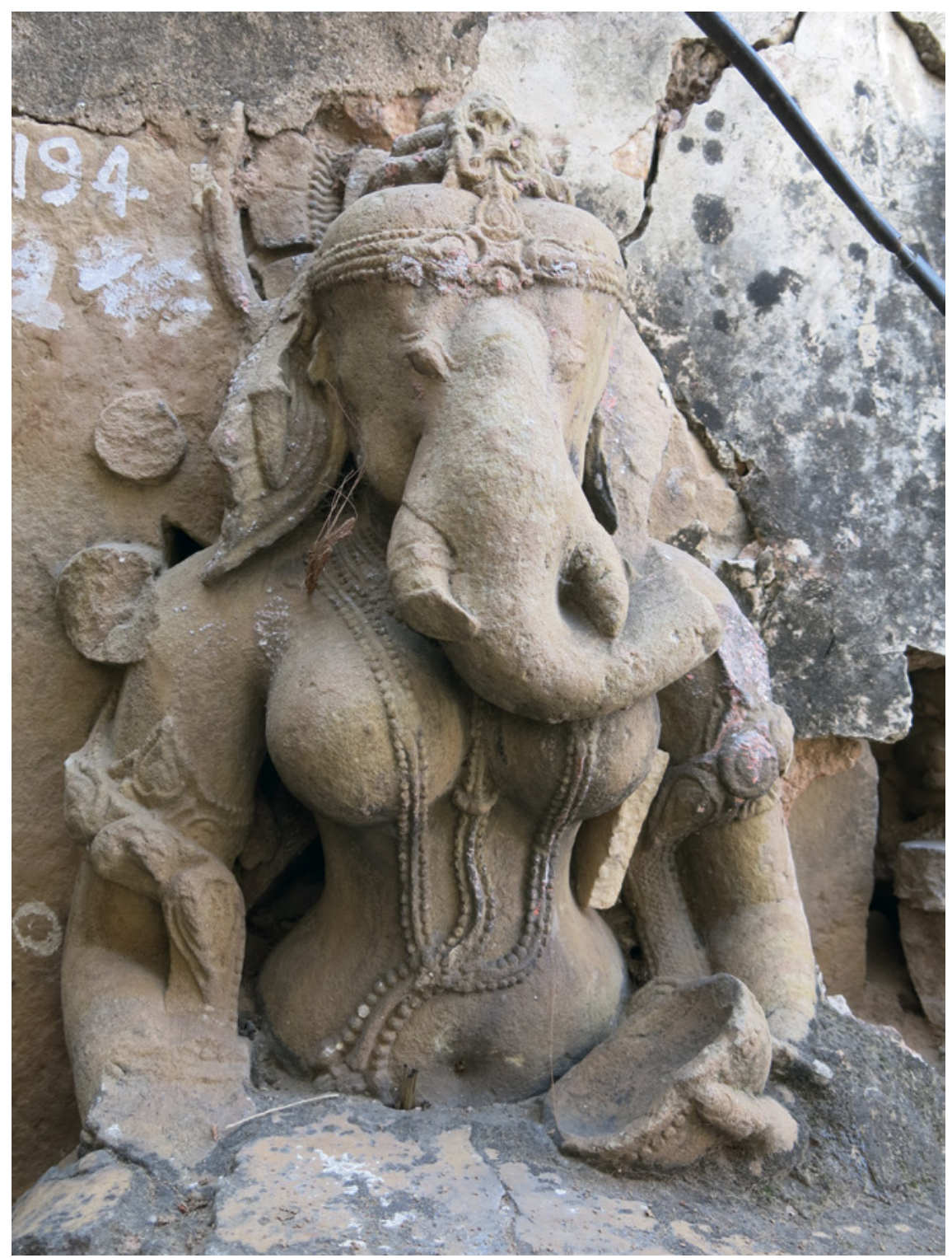

FIGURE 48

Elephant-headed yoginī with wine cup, sculpture repurposed in niche outside Bhairava shrine, Harṣa Temple complex, c. 9th-1oth century

plausible that the contemporary use of this area and its association with the goddesses preserve echoes of a much earlier and enduring association of this place with the Mothers and the yoginis. 


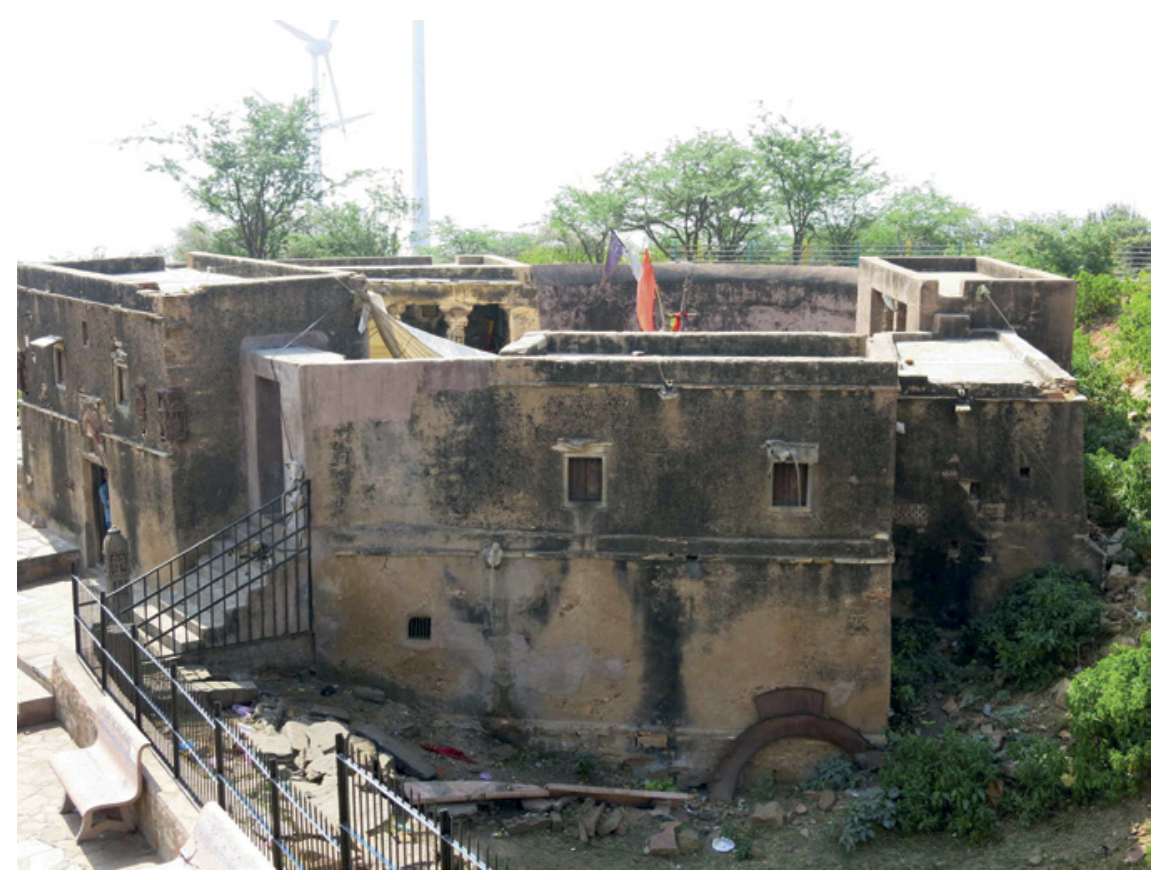

FIGURE 49 Open-air complex, now an active Bhairava shrine, Harșa Temple complex

In light of the numerous images of Viṣnu, Sūrya, and the Goddess preserved at Harșa, monumental sculptures of Śiva himself are conspicuous in their absence. I have identified the remains of only one large icon on site-the upper portion of a five-faced Sadāśiva displaying a fearsome expression. Those taken to the Sikar museum are part of architectural fragments suited to adorn external temple niches, but not to serve as the primary image under worship in the temple. The only other icon I have found that fits this latter description is now on display at the State Archaeological Museum in Ajmer. The remarkable image depicts a four-faced (caturmukha) Śiva linga, with the major deities of the Hindu pantheon—Brahmā, Vișṇu, Sūrya, and Śiva—positioned around the base [Figure 50]. This iconic representation of Siva and arrangement of deities in a single sculpture is rare. Given that the central image is the linga, it materializes a Śaiva theology. At the same time, the presence of the other deities encircling the base suggests a more inclusive religious vision whereby these deities are incorporated within the Śaiva religious hierarchy. One other important image from Harșa on display in Ajmer materializes a similar hierarchical, yet ultimately inclusive vision [Figure 51]. The image, called a lingodbhavamürti, represents an important event in Śaiva mythology in which 


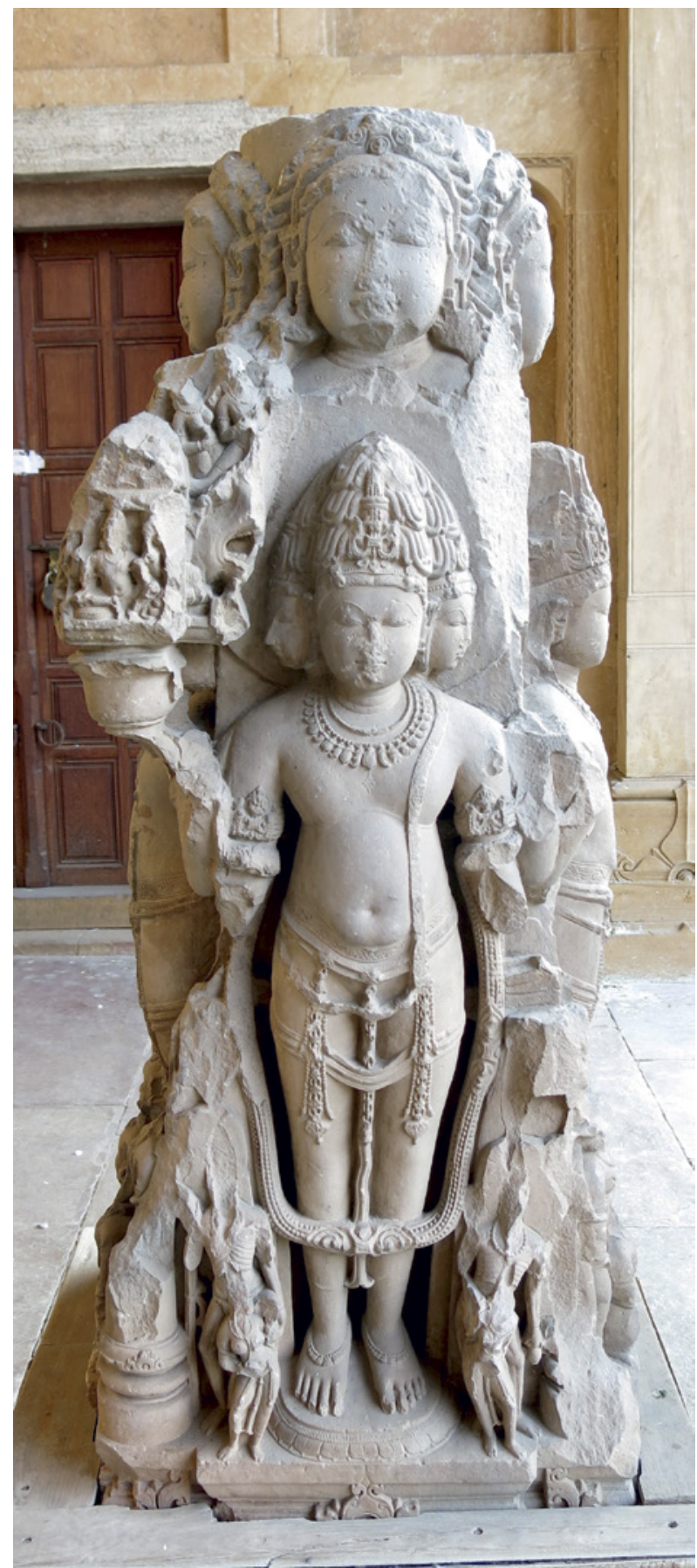

FIGURE 50 Pañcāyatana linga from Mt. Harṣa Temple complex, c. 9th-1oth century

AJMER GOVERNMENT MUSEUM 


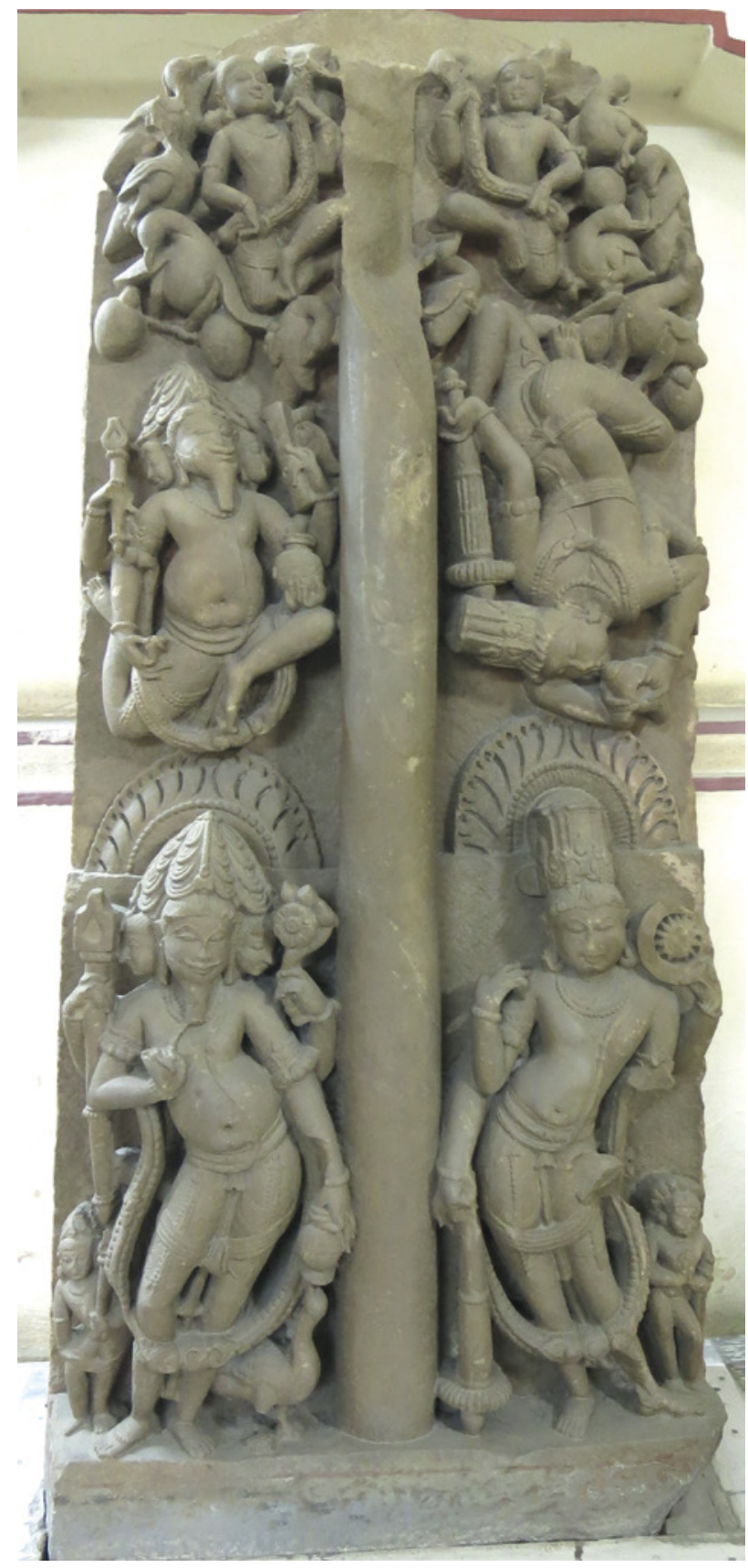

FIGURE 51

Lingodbhavamūrti from Mt. Harșa Temple complex, c. 9th-10th century AJMER GOVERNMENT MUSEUM 
Siva manifests himself to Viṣnu and Brahmā as a fiery, endless linga of light. ${ }^{49}$ The two gods are confounded by Siva's infinite power and forced to admit his supremacy. Considering these displaced sculptures as part of the larger material archive, an important resonance between visual and spatial expressions of religious hierarchy at Mt. Harșa becomes evident: the position of Śiva at the center of the monumental linga echoes the articulation of shrines on Mt. Harșa. The dominance of Siva was established by locating the linga shrine at the center of the complex, where it served as the primary focal point around which the other smaller shrines dedicated to other deities were clustered.

This chapter has shown how Śaiva religiosity provided a powerful vocabulary for sovereignty that served to legitimize the Cāhamāna's fledgling royal identity while also publicizing the pious works of Pāsupata religious specialists. Whether deployed in support of rulers or to champion the ascetic ideal, these expressions were inextricably tied to the regional landscape. The temple to Lord Harșa served as a materialization of this identity of lineage, place, and deity. But political elites and religious specialists were not the only groups who expressed belonging though investment in Śaiva institutions. For the merchant groups expanding their communities in new settlement areas in the northwest frontier, establishing temples to localized manifestations of Siva also initiated processes of community-building and place-making. To illustrate these processes in practice, the concluding section of this chapter introduces the village of Kāman, a thriving merchant settlement oriented around the temple to Śiva as Kāmyakeśvara, the town's tutelary deity. Although contemporaneous with Harșa, the representations of Śiva devotion at Kāman developed a distinct, locally inflected character that reflected the economic mobility and social aspirations of the residents of the market town.

Located in an area that straddles the borders of the Bharatpur and Alwar Districts of Rajasthan, approximately $300 \mathrm{~km}$ east of Harṣa, Kāman's position at a geographic interface between the desert and the urban centers along the

49 For this myth, see Nirajan Kafle, "The Lingodbhava Myth in Early Śaiva Sources," in: Pușpikā. Tracing Ancient India Through Texts and Traditions. Contributions to Current Research in Indology, eds. N. Mirnig, P.-D. Szántó \& M. Williams (Oxbow: Oxbow Books, 2013), 241-263. 
Yamunā River made it an unlikely political capital, but ideal as a center of economic exchange. Architectural and epigraphic evidence indicates that in the late 8th century Kāman emerged as a frontier 'boomtown'—a settlement characterized by a burgeoning and newly affluent population. ${ }^{50}$ Evidence of Kāman's economic boom is preserved in a rich material archive that includes remains of monumental architecture, stone inscriptions, and finely crafted sculpture. The medieval residents appear as great patrons who gave liberally to religious institutions, including to temples of Viṣnu, Śiva, the Goddess, and Sūrya. This remarkable artistic legacy would have required an economic surplus sufficient to support ateliers of skilled artisans and craftspeople. The most significant remains have been dated to the late 8 th and early 9 th century CE ${ }^{51}$ Judging by the material record, this prosperous period extended to the 11th century, after which point there is little evidence for the continued construction of brahmanical temple architecture. ${ }^{52}$

Despite the richness of the sources, there has not yet been an effort to evaluate the early material legacy of this place together with the epigraphic sources or in light of the contemporaneous material evidence from Satwas, a village located only a few kilometers away. I think there are two reasons for this historiographical anonymity. Kāman was not a major political capital, nor are its inscriptions revelatory of Imperial dynastic history or genealogy. Second, nothing is where it once was. The material remains are all removed

$5^{0}$ While the phrase 'frontier boomtown' may evoke a vision of lawlessness characteristic of the Wild West of American folklore, this term is used more precisely here to describe a scenario of rapid population growth and development inspired by economic opportunity. On this term see Gunther Barth, Instant Cities: Urbanization and the Rise of San Francisco and Denver (Oxford: Oxford University Press, 1975); E. Bradford Burns, "Manaus 1910: Portrait of a Boom Town," Journal of Inter-American Studies 7.3 (1965): 400-421.

$5^{1}$ The epigraphic corpus records donations made between 787-906 CE. Michael Meister observes shared architectural and iconographic patterns between Kāman and temples from 8th-9th century CE in Marwar, Kanauj, Gwalior, and important sites like Abhaneri and Harșa in Cāhamāna-controlled regions of Rajasthan. These parallels are discussed in further detail in the pages that follow. See Michael Meister, "Śūrasenas of Śrīpatha," 217-221 in EITA 2.2 .

52 This break in the development of the built religious landscape coincides with the intensification of Islamic activity in the region, which likely disrupted the established economic networks that had supported artistic production in the area. By the early 12th century, Kāman's largely Śaiva institutions had been repurposed and reimagined in the creation of Ghurid Islamic architecture. Alka Patel, "Recasting the Architectural Landscape: The Late 12th-Early 13th-century Ghurid Annexations of Northern India," in Prajñädhara: Essays in honor of Gouriswar Bhattacharya, eds. Arundhati Banerji and Gerd J.R. Mevissen (Delhi: Kaveri Books, 2009), 122-135. 
from their original architectural contexts. The town is a palimpsest, layered with hybrid structures that were refashioned over time with materials from different historical periods. Other important sculptures from Kāman are distributed across several of Rajasthan's Government Museums, which makes it difficult to discern particular collections in the material archive. Despite these challenges, working to recover a particular historical moment-a period from approximately the end of the 8th century to the early years of the 1oth century when this area was truly booming - reveals the impact of regional economy and economic actors in the growth of religious institutions in Kāman and the role of these institutions in processes of place-making. ${ }^{53}$ Doing so reveals a socially supported and irenic vision of Śaiva religiosity not represented at Harșa. In Kāman, Śiva was neither fearsome warrior nor renunciant; rather, he was imagined as a prosperous family man.

\subsection{Kämyaka \& Kāmyakeśvara}

Inscriptions found in and around the village describe Kāman (or Kāmyaka, as it was called) as a fortified town (kotta $a$ and as a market or exchange center (hatța). Small fortified settlements like Kāman became active commercial centers that attracted collectives of merchants and traders who established new communities in these places. ${ }^{54}$ While participating in the shifting trajectories of early medieval settlement and economy, Kāman's particular prosperity resulted from its position within regional and transregional networks of mobility and exchange. ${ }^{55}$ With Delhi and Mathura to the north and east and Gwalior to the south, Kāman was positioned at the intersection of major political

53 The definition of place-making proposed by Pierce, Martin, and Murphy informs my use of the term. "Place-making - the set of social, political and material processes by which people iteratively create and recreate the experienced geographies in which they live-is an important but oft-neglected part of political theory. Place-making is an inherently networked process, constituted by the socio-spatial relationships that link individuals together through a common place-frame." Joseph Pierce, Deborah G. Martin and James T. Murphy, "Relational Place-Making:The Networked Politics of Place," Transactions of the Institute of British Geographers New Series, 36.1 (2011): 54-70.

54 Chattopadhyaya, The Making of Early Medieval India, 89-119. For example, groups like the Dhūsara and Dharkața merchants (vaniks; śreșthīs) figure as temple donors in inscriptions from Khandela, Mandikila Tal, and Sakrai in northeast Rajasthan: D.C. Sircar, "Khandela Inscription of Year 201," EI 34 (1961-62): 159-163; B.Ch. Chhabra, "Mandkila Tal Inscription," EI 34 (1961-62): 77-90; B.Ch. Chhabra, "Sakrai Stone Inscription; V.S., 699," EI 27: 27-33.

55 I emphasize the geographic and economic factors since there is no evidence in inscriptions to suggest it was the capital of an imperial lineage. 
borders and networks of economic exchange that linked these polities to sites in the northwest frontiers of Rajasthan. The town was also located along the highway that linked Delhi to Bāyāna, the regional customs and toll house. The surrounding physical terrain protected the settlement, which was positioned within a naturally fortified area, enclosed by a run of low-lying hills and a river on the northeast side.

In addition to marking a clear geographic center within the settled area, Kāman's religious institutions also provided an ideological center where expressions of social identity and belonging were enacted and materialized. Among the donors whose acts of pious giving have survived through the enduring medium of stone, the voices of merchant groups, traders, and artisans are particularly prominent. And the area's remarkable artistic legacy—preserved in the remains of monumental architecture and finely crafted sculpture-similarly indicates an economic surplus sufficient to support ateliers of skilled artisans and craftspeople. The most compelling evidence for the imbrication of community and place comes from two 'collective' inscriptions that record a series of donations made between the late 8th and early 1oth century. Collective records like this one, for which comparable examples have been found at Āhār and Sìyadonī, ${ }^{56}$ were composed over a considerable period of time and demonstrate the extent to which a sanctified center becomes a site for community building by recording a wide range of social participation. In this case, the majority of donative activity was directed to the temple of Kāmyakeśvarapresumably a linga shrine dedicated to a locally venerated form of Śiva, the tutelary deity of the eponymous town. There is still an old caturmukha linga called Kāmyakeśvara under active worship within the fortified center of the town [Figure 52]. The linga is worn from ritual activity and difficult to date with certainty, but given the position of the temple in a place of prominence beside the entrance to the old fortified center, it could plausibly preserve remains from the early medieval temple to the locally venerated Śiva.

\subsection{Corporate Religion}

The centrality of Kāman's religious institutions for social life and communitybuilding is evident also in the siting of the architectural remains, which provided a point of orientation, a central axis around which the market town developed. The old settlement mound is surrounded by remains of walls and other fortifications. It is within this fortified center that the majority of the

56 D.R. Sahni, "Ahar Stone Inscription," EI 19 (1927): 52-54; F. Kielhorn, "Siyadoni Stone Inscription," EI 1 (1892): 162-179. 


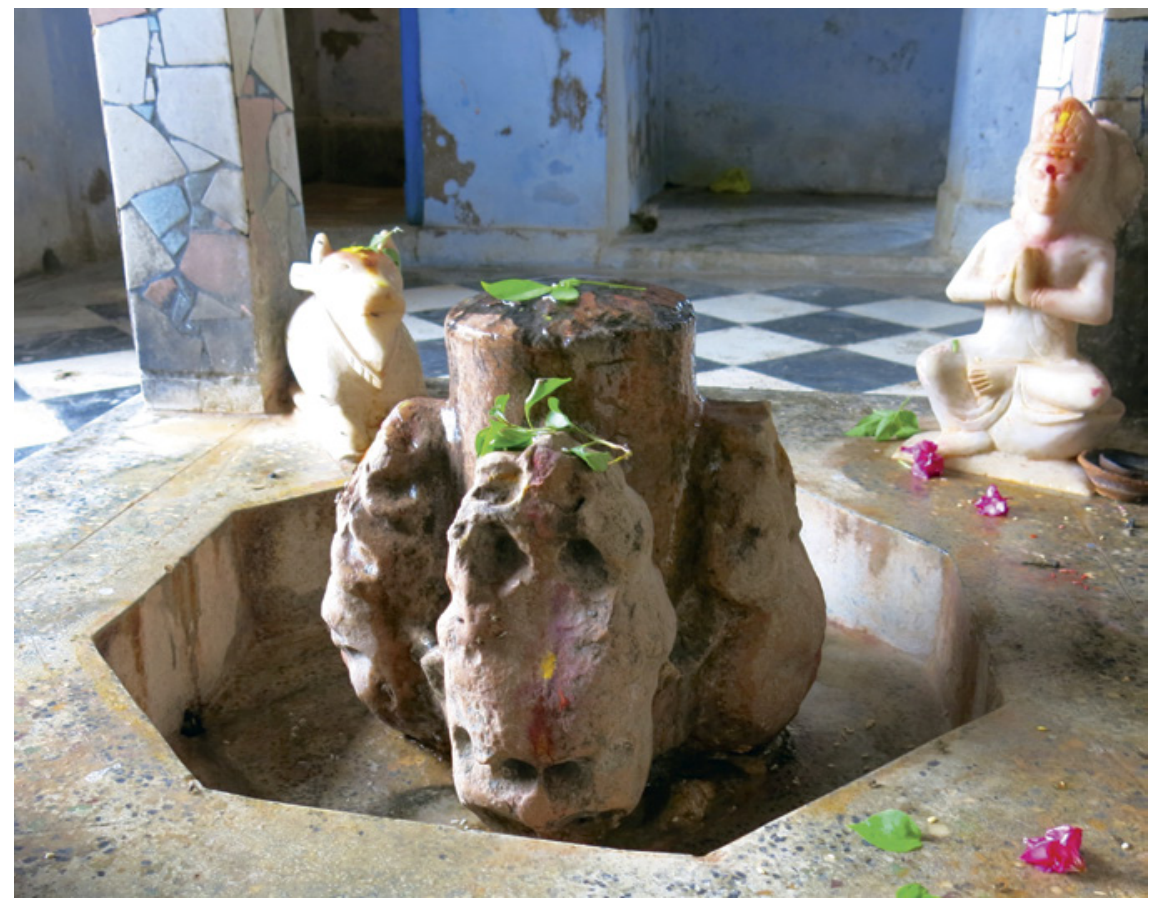

FIGURE 52 Linga called Kāmyakeśvara under worship, Kāman

remains of temples and other forms of material evidence are preserved. In his 1882-83 report, Cunningham describes the massive mound of the old fortified settlement extending 30 feet in height on the east and 50 feet on the west. ${ }^{57}$ R.D. Banerji gives a similar assessment and comments that the high mound consists primarily of the remains of temples. ${ }^{58}$ Atop this mound stands the Chaurāsī Khambhā (the 'Hall of 84 Pillars') one of the earliest mosques of India built from the repurposed elements of earlier Hindu monuments [Figure 53]. As a monument of critical importance for early Islamic architecture in India, the Chaurāsī Khambhā has been the subject of important scholarly works. ${ }^{59}$

57 Alexander Cunningham, Report of a Tour in Eastern Rajputana 1882-1883 (Calcutta: Archaeological Survey of India), 54-60.

58 Progress Report, Archaeological Survey of India, Western Circle, 1919, 64-65.

59 Notably by Alka Patel, "Recasting the Architectural Landscape"; Finbarr B. Flood, Objects of Translation: Material Culture and the Medieval 'Hindu-Muslim' Encounter (Princeton: Princeton University Press, 2009), 144; Michael Meister, "Indian Islam's Lotus Throne: Kaman and Khatu Kalan," in Islam and Indian Religions, 2 vols., eds. A.L. Dallapiccola and S. Zingel-Ave Lallemant (Stuttgart: Franz Steiner Verlag, 1993), 445-452. As the latter two scholars note, the Chaurāsī Khambhā preserves the earliest in situ minbar in India. 


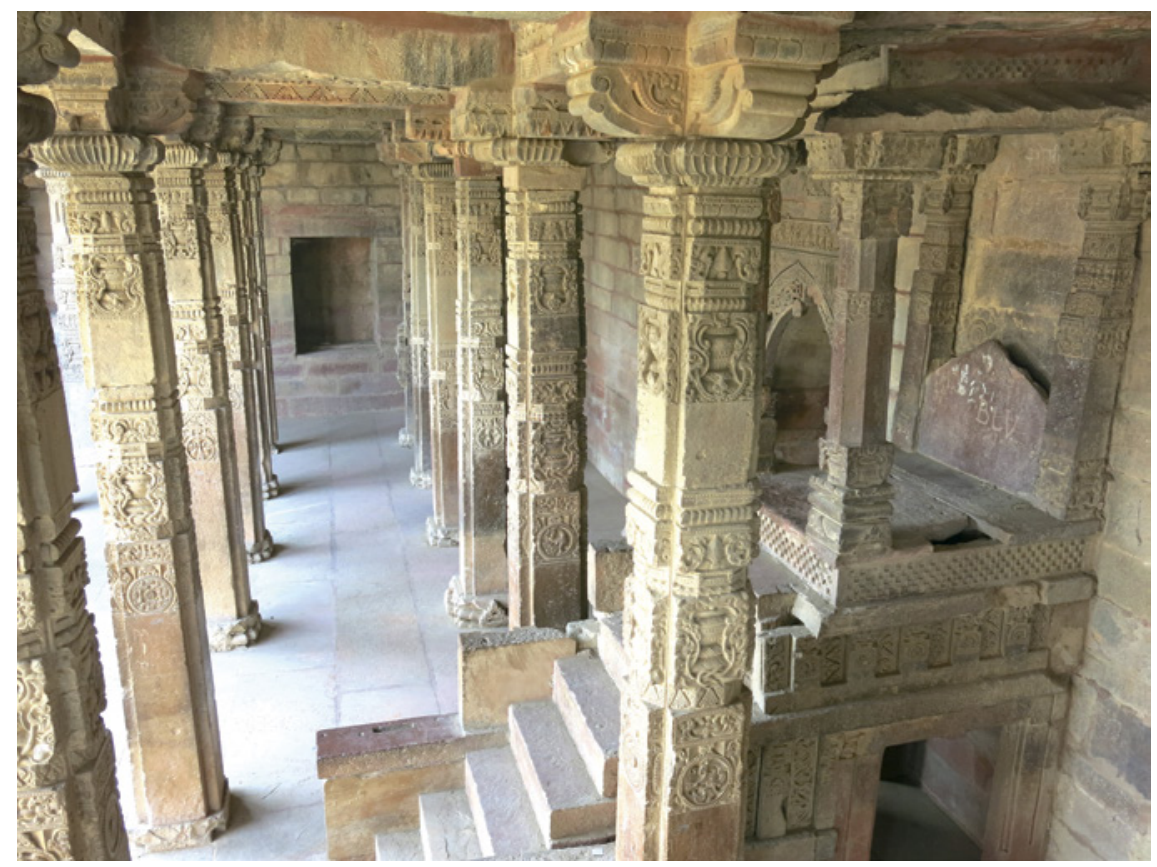

FIGURE 53 Chaurāsī Khambhā, view of minbar made of repurposed temple elements, Kāman

Judging from the $1204 \mathrm{CE}$ date of the dedicatory inscription framing the mihrāb, this transition of the monumental religious centre from a brahmanical to an Islamic space was completed by the late 12 th or early 13 th century. ${ }^{60}$

This mosque was built of repurposed architectural fragments from Hindu temples with some surviving Śaiva and Vaiṣnava iconography [Figure 54]. From the color and varieties of stone - ranging in shades of buff, tan, pink, and red-and the different decorative elements and patterns of embellishment on the reused pillars and fragments, we may assume multiple temples and monuments were utilized in the construction of this mosque. The elements of the surviving fragments also attest to the position of Kāman vis-à-vis artistic currents at contemporaneous sites. For example, Michael Meister notes parallels between the decorative elements at Kāman and those from pillars at Osian, Chittorgarh, and Menal in Rajasthan from the mid-8th to late 8th century. ${ }^{61}$

6 Z.A. Desai, "Islamic Inscriptions: Their Bearing on Monuments," in Indian Epigraphy, its Bearing on the History of Art, eds. Frederick M. Asher and G.S. Gai (New Delhi: American Institute of Indian Studies, 1985), 252.

61

EITA 2.2, 217-221. 


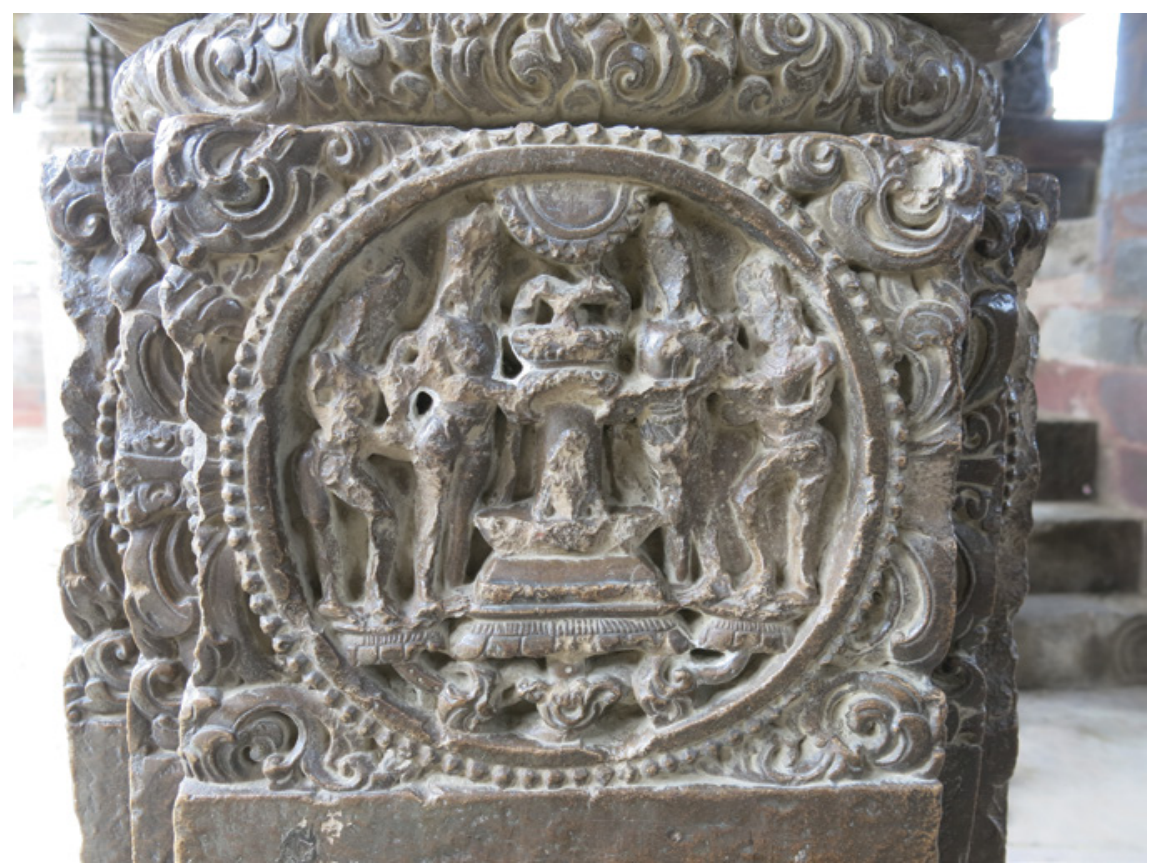

FIGURE 54

Scene of linga veneration on pillar in the Chaurāsī Khambhā

Three stone inscriptions have been reported from Kāman. ${ }^{62}$ For the purpose of convenience, I have referred to these as $\mathrm{K}_{1}, \mathrm{~K}_{2}$, and $\mathrm{K}_{3}$ in the pages that follow. Two of these (K1 and $\left.\mathrm{K}_{3}\right)$ are now rebuilt within the Chaurāsī Khambhā. Inscription $\mathrm{K}_{2}$ was reportedly found in a well outside of the city. The mosque featured a number of prominently placed inscriptions of verses from the 'Qurān, and it may be that this attention to the Islamic monuments epigraphic program motivated the display of medieval Sanskrit inscriptions that refer to the earlier lives and contexts of the architectural elements. The inscriptions thus serve as a visual display of the replacement of one religious ideology by another. The two repurposed epigraphs are 'collective' inscriptions that record a series of donations made between the late 8th and early 1oth century.

62 Three early medieval inscriptions have been reported: two on repurposed temple fragments now built the Chaurāsī Khambhā. The first is undated but assigned to the 8th or 9th century based on paleography. It records the donation of a Viṣnu temple by grandmother of Sūrasena ruler Vatsadāman. The second, dated H.S. 263/869 CE records the pious works of a collective body of trustees who are evidently devotees of Siva. The third is a record of collective donations made to temples, among them the temple for Kāmyakeśvara. These records are discussed in further detail below. 
Undertaking these acts as community activities allowed people of comparatively modest means the opportunity to participate in donative activities far beyond their economic reach as individuals.

In the collective records from Kāman, donative activity was directed, in particular, toward the temple of Kāmyakeśvara. All three of the inscriptions are heavily damaged, but we can still recover some details. The endowing of temples is represented in these epigraphic sources as the result of cooperation between Śaiva religious specialists, merchant communities, guilds, artisans, and local political elites. These religious centers were storehouses of wealth, both material and symbolic. They controlled significant immovable assets (for example, market stalls and fields) and participated in the monetized economythrough rents paid in cash, and taxes paid to the temple by guilds and traders. I will illustrate some of these interactions with a few examples.

$\mathrm{K} 1$ - This inscription is positioned on its side built in the interior of the entryway [Figure 55]. It is undated, but has been assigned to the 8th or 9th century based on paleography. It records the donation of a Viṣnu temple by Vachikā, the grandmother of Śñrasena ruler Vatsadāman. ${ }^{63}$ The inscription also provides a genealogy of seven rulers of this 'dynasty', as it has been termed, although this record is the only one of two inscriptions attesting to their rule. ${ }^{64}$ The record suggests that Kāman, while not a regional seat of power, was integrated within political networks. Perhaps as a kind of satellite marker center connected to the main Śrīpatha Maṇdapikā at Bāyāṇa. ${ }^{65}$

K2-This stone inscription, with dates recorded between H.S. 180-299/ $786-87-905-6 \mathrm{CE}$, was found in a well outside the city. ${ }^{66}$ The record is extremely fragmentary and difficult to reconstruct in full, but some important details have been preserved. It begins with an invocation to Śiva and praise of a brahmin by the name of Kakkuka who, together with his sons, contributed to the construction of a mațha. This mațha appears to have been a Pāśupata centre. Although it is badly damaged, the names of two of the ācāryas end with the -rāśi suffix common amongst initiated Pāśupata-for example, we

63 Bhagawanlal Indraji, "Inscription from Kāmā or Kāmavana," IA 10 (1881): 34-36.

64 R.D. Banerji, "The Bayana Inscription of Chittralekha: V.S. 1012," EI 24 (1933-34): 120-127. This 1oth century inscription from Bayānā mentions the Sūrasena family again in the context of Viṣnu worship and records the implementation of taxes at market places to support the worship of the deity.

65 Chattopadhyaya, The Making of Early Medieval India, 9.

66 V.V. Mirashi, 'Kaman Stone Inscription,' EI 24 (1937-38): 329-335. 


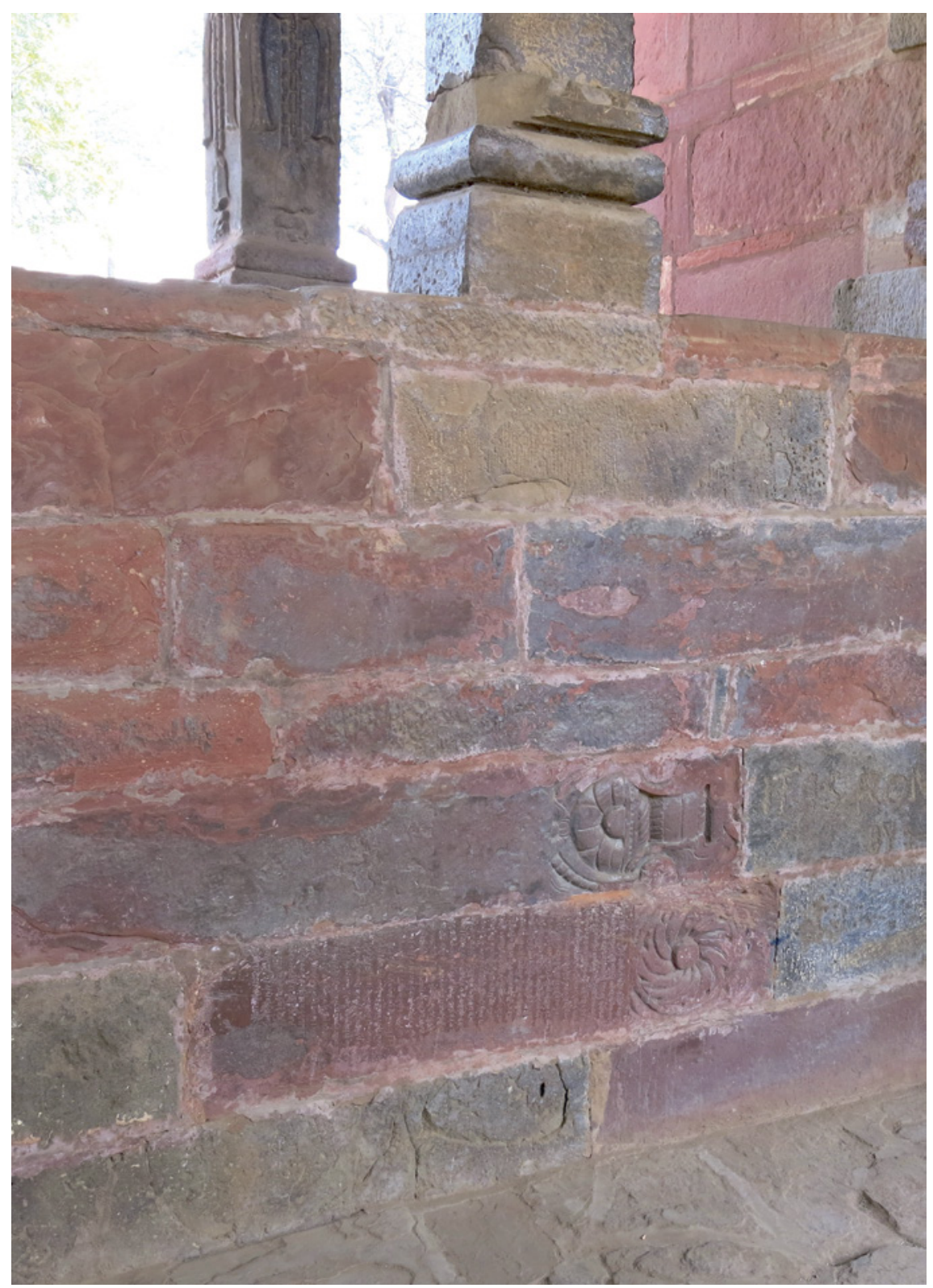

FIGURE 55 Chaurāsī Khambhā, inscription in interior wall 
have mentioned here Gunarāši and Pramānarāśi. ${ }^{67}$ After the record of the endowment of the mațha and the Pāśupata lineage, seven individually dated sections follow commemorating donations made to the temple of the deity Kāmyakeśvara, the locally venerated form of Śiva. It seems that the monastic complex was part of, or perhaps a later addition to the temple complex.

Kāman was also a regional commercial center. A donation from the same collective record, made in $905 \mathrm{CE}$, mentions a cattle market (kambali-hatța) that had enclosures ( $\bar{a} v \bar{a} r i k \bar{a} s)$ with shops (vithiss), details that seem to suggest that this was not a seasonal or moving fair, but, rather a permanent market. This would accord with the records of endowments of land, wells and money by individual merchants, artisans, and collectives (goșthikas) preserved in the inscription. Some of these donations were in the form of a voluntary tax or tithe. Others were permanent endowments by artisan collectives or guilds (śreni). For example, a potter's guild agreed to pay one pana per wheel each month for the maintenance of the temple. ${ }^{68}$ A guild of gardeners pledged a permanent endowment of garlands to shrines of Viṣnu and Cāmuṇạā, presumably located within the same Śaiva temple complex. ${ }^{69}$ The carpenters (sthapati) living in Kāman also give a tithe of one dramma per month. Other donations were made by individuals and included small measures of land and market enclosures. The final section of the record contains some interesting evidence attesting to the entrepreneurial spirit of the Śaiva religious specialists-here a donation to the temple deposited with the Pāśupata Pramānarāāí, was, after his death, invested with a goșthī by his successor, Cāmunḍaka. ${ }^{70}$ The donations attest clearly to the integration of the Kāmyakeśvara temple within the local economy ${ }^{71}$ —even the Śaiva a ācarryas were investing in local market real estate. In addition to an economic activity, the community-wide investment in the Kāmyakeśvara temple also functions as an act of place-making. When recording their donations, the guilds and artisans specifically identify themselves as residents of Kāmyaka. This emphasis on place can be read as an expression of identity between the residents, the town, and patron deity and an effort to ensure tangible and enduring links between them.

67 Gunarāśi appears in Line 10 end-Line 11. Pramāṇarāśi is mentioned in the final donation at Lines 22-24.

68 Donation made in H.S. 229; Lines 13-17.

69 Donation made in H.S. 232; Lines 17-18.

70 Donation in H.S. 299; Lines 22-24.

71 Lines 13-17 record a donation in H.S. 229 to Kāmyakeśvara for two sections of land in the fortified area (Line 13; Line 15 refers to the kotta) of the town made by one vanik named Vajjrata (Line 13). Further references to the structures within the city area in Line 22-24; Donation from H.S. 299. 


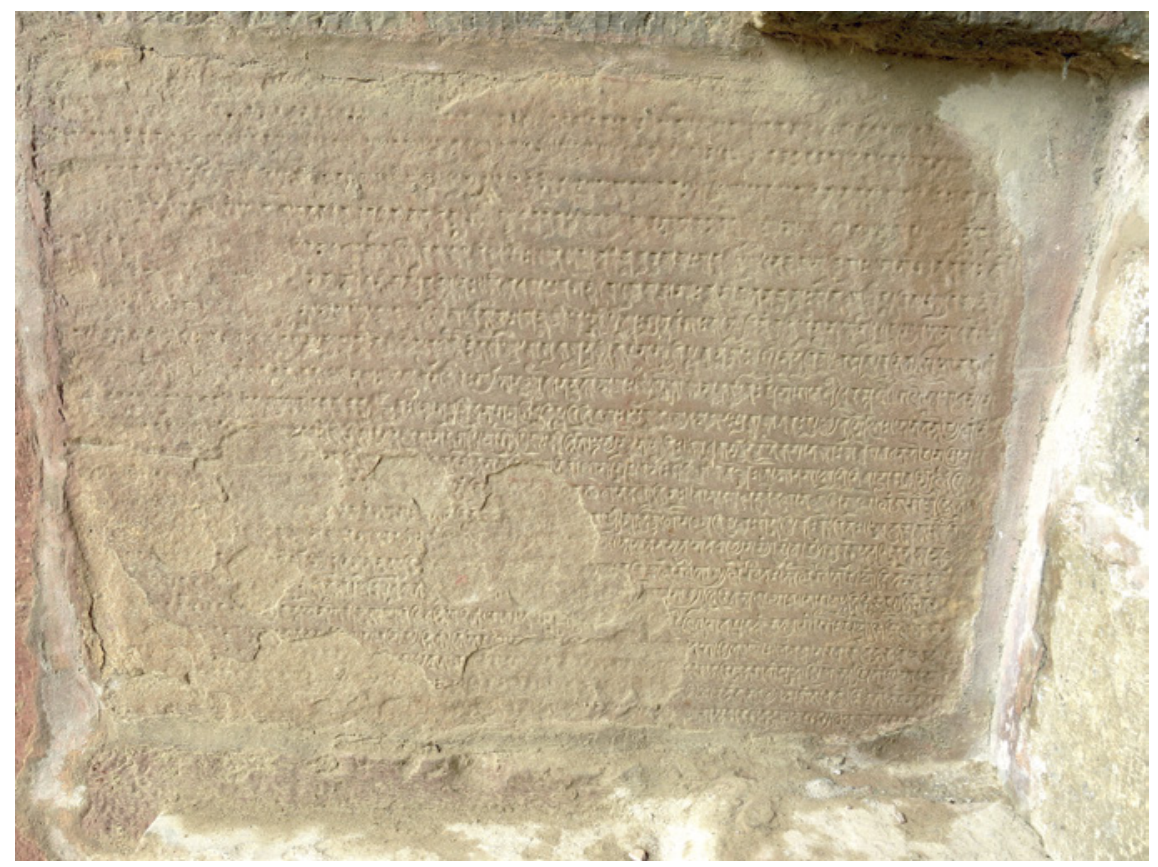

FIGURE 56 Chaurāsī Khambhā, inscription in exterior wall

$\mathrm{K}_{3}$-An inscription on the exterior framing wall of the Chaurāsì Khambhā, dated H.S. 263/869 CE, records the pious works of a collective body of trustees who are evidently devotees of Śiva (maheśapriyā goșthikāh) [Figure 56$].{ }^{72}$ In particular, three sons of Iśāna are mentioned (Nāgața, Siddhanāga, Sivaviṣnu) who oversee the building of a tank $(v \bar{a} p \bar{\imath})$ and a monastic residence (mața) in honor of their father. ${ }^{73}$ Line 20, padas c and d in Śārdūlavikrīịita meter refer to a temple or institution established for (at least) three deities:

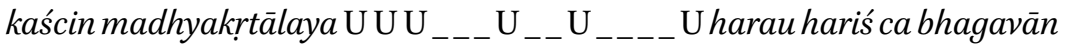 sadgoșthikai sthāpitāh

Two of the deities, Hara and Hari (i.e. Śiva and Viṣnu) are named and I suggest that we consider Sūrya as the third member of a presumed triad of deities. We could then amend the line to read: püjyau sūryaharau hariś ca bhagavān. In addition to conforming to the meter-which Umā or Pārvatī does not; Brahmā

72 D.C. Sircar, "Three Inscriptions from Rajasthan," EI 36 (1961): 47-56. Line 11.

73 Line 10. 
is also unlikely since he is very rarely the recipient of a temple - the addition of Sūrya fits well with the material remains from Kāman, as well as larger regional patterns, which articulate a close association between Sūrya and Śiva as described earlier in relation to material from Harṣagiri.

\subsection{Sūrya and Śiva in Satwas}

Satwas, a small village just a few kilometers north of Kāman preserves remains of two Sūrya temples, one pictured here, framed by a lintel that displays Lakuliśa in the central niche. Directly beside it are remains of a Siva temple with an enshrined linga [Figures 57 \& 58]. In this temple, an image of Sürya adorns the central niche of the doorframe. These temple doorframes are clearly rebuilt with contemporary structural elements, and my initial impression was that in the process of rebuilding they may have been switched and, as a result, the doorframe with Sürya in the niche frames a linga shrine, and Lakulīśa, the emblem of the Pāśupata Śaiva tradition, frames the Sūrya shrine. Switched or not, I do not think that these doorframes have travelled far from their original contexts. In addition to their spatial proximity, other features suggest they were conceived as part of a set. For example: their nearly identical size and shared artistic features: framing vyālas, decorative elements,

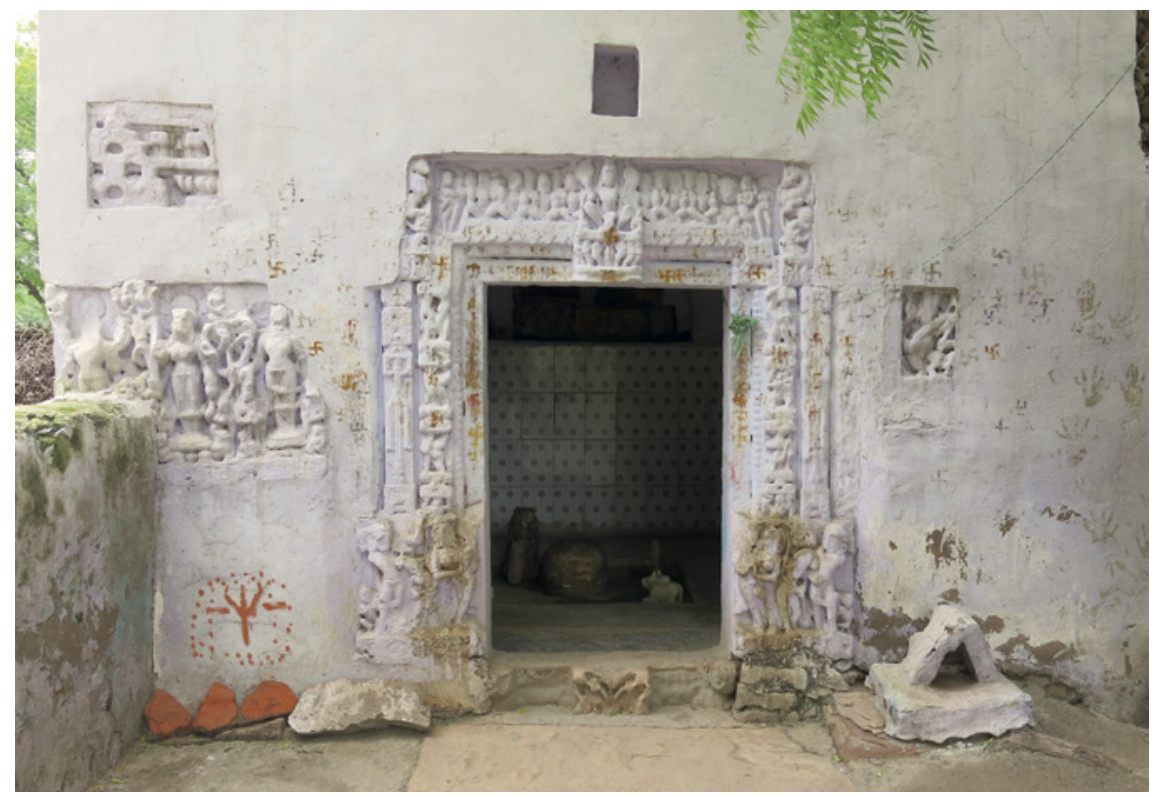

FIGURE 57 Linga shrine with Sūrya in central lintel niche, Satwas village, c. 8th-9th century 


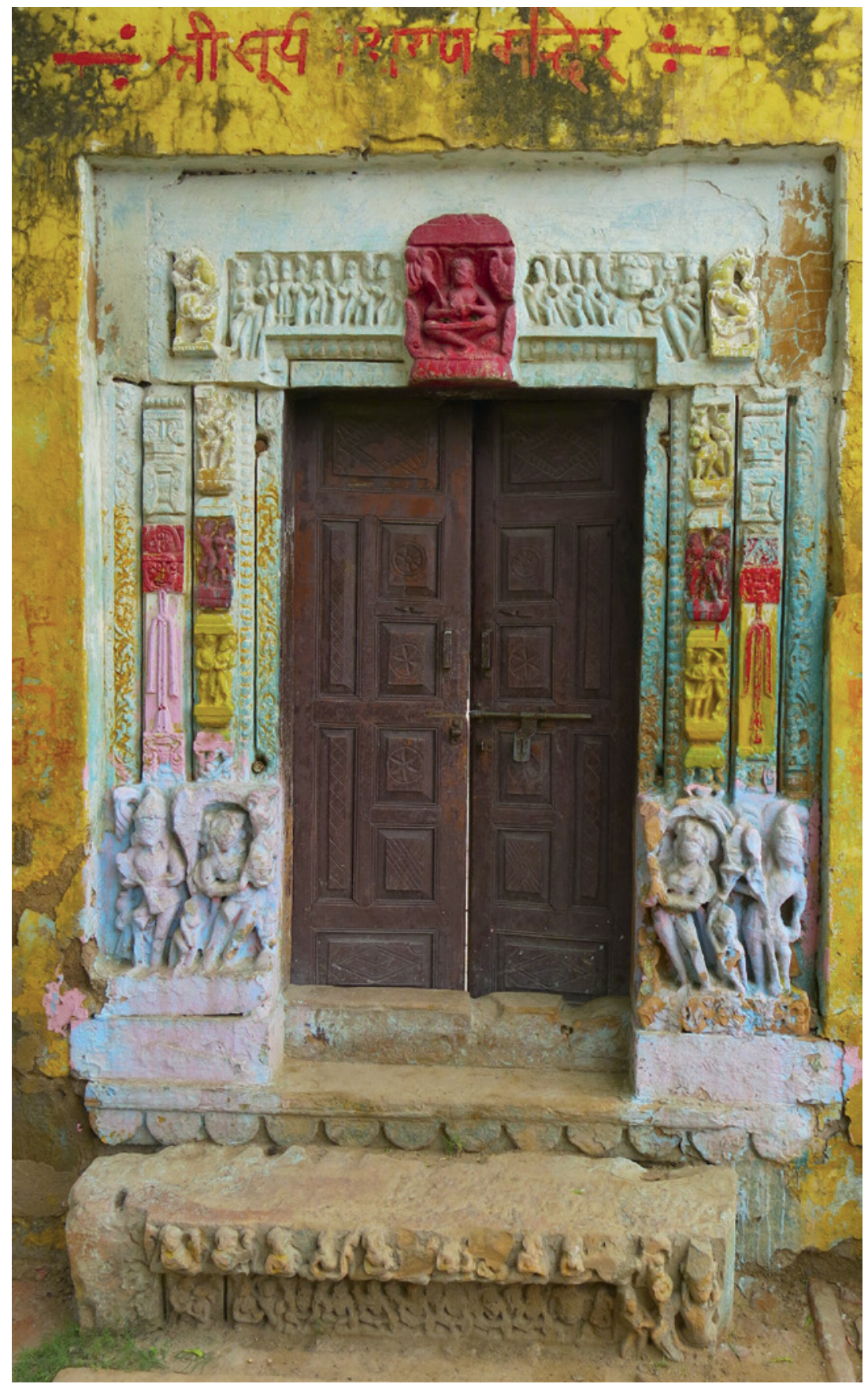

FIGURE 58

Sūrya shrine with Lakulīśa in central lintel niche, Satwas village,

c. 8th-9th century 


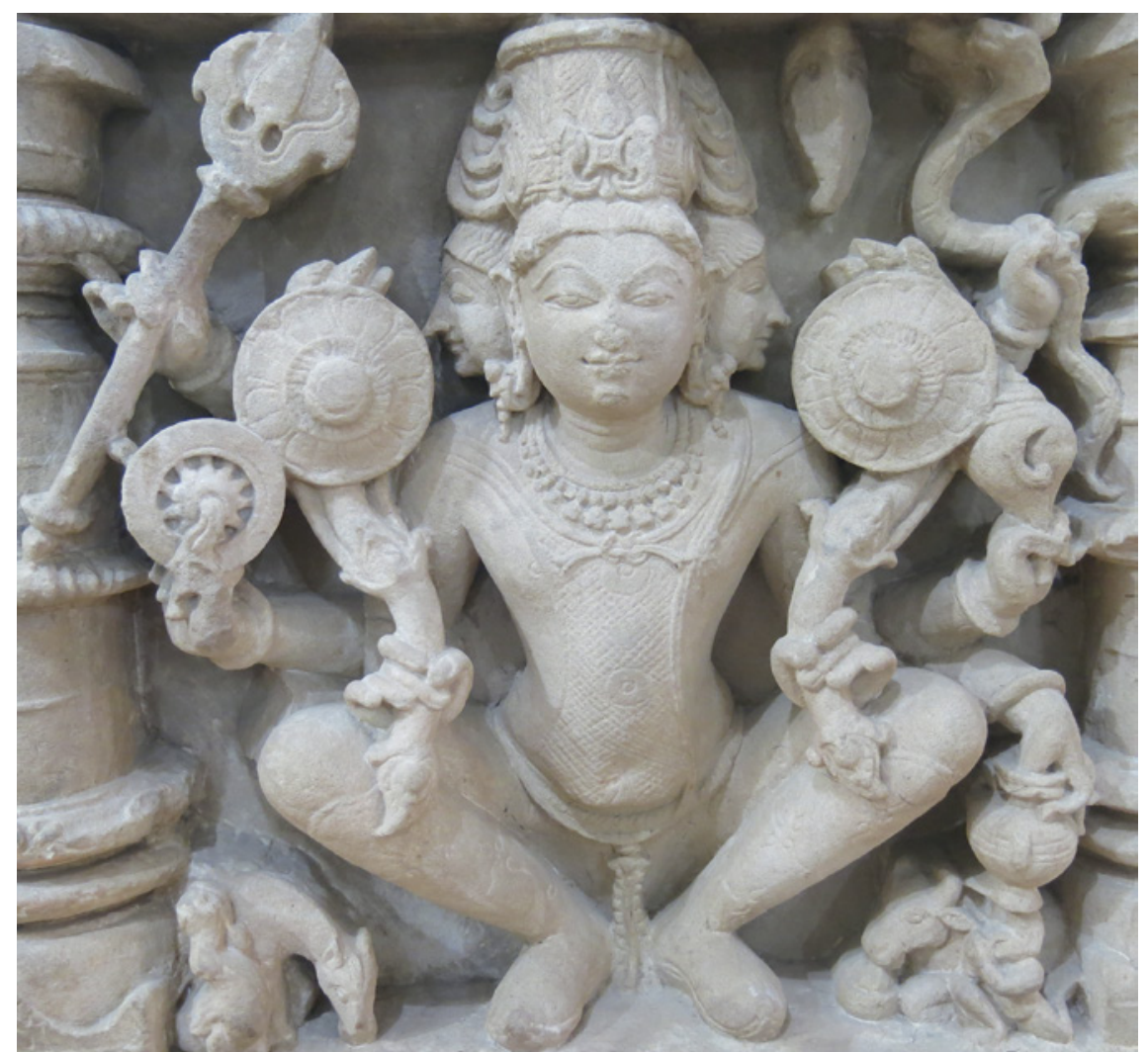

FIGURE 59 Hariharapitāmahamārtand dִa from Mt. Harșa, c. late 9th-early 1oth century SIKAR GOVERNMENT MUSEUM

the proximate size of the central images, and the shared navagraha frame. The spatial proximity of the linga and Sürya shrines similarly suggests an affinity, or 'intervisibility', between these deities.

A comparable expression of this intervisibility appears in incorporative forms of Śiva and Sūrya, that begin to appear in this region in the 9th century. In images from the nearby site of Mt. Harșa, Sūrya appears consistently as the central deity [Figure 59]. By contrast, in a monumental linga from Kāman, a quartet of major Hindu deities, including Sūrya, encircle the emblem of Śiva [see Figure 50]. Albeit manifestations of different religious hierarchies, we can read the impetus for inclusion as a strategy that incorporated both a growing community of Śiva worshippers while acknowledging the long history of Sūrya worship in the area. Kāman's paired Śiva and Sūrya shrines could anticipate this regional trend. Following my interpretation, the juxtaposition of the Śaiva 
and Saura icons and images in these temples reflects a conscious decision on the part of the artists or donors to give visual expression to a theological concept. The intervisibility expressed through the framing images in the lintels is then another artistic strategy used to express the same religious ideology that we see communicated through incorporative icons like that of Figure 59.

In addition to attesting to a possible connection between mention of Śiva and a third deity (possibly Sūrya), the inscription explicitly mentions Viṣnu as well. I did not find evidence for a third shrine in the temple complex mentioned above, but the importance of Viṣnu worship is clearly suggested in the epigraphic and iconographic remains. One of the most remarkable sculptures from Kāman is that of Viṣnu's boar avatāra, Varāha. Following my argument that we can read Kāman's art and architecture as both 'models of' and 'models for' community, uniquely inspired by and adapted to address the concerns of the people who used them, a triadic temple structure could well have been another strategic effort toward an integrative hierarchy in which Śiva, in the middle, central position was flanked by Sūrya and Viṣnu, respectively. It could be that a triple-celled shrine housing these three deities is what the record describes. Temples of this sort are rare, but not unprecedented. Two significant and contemporaneous examples are preserved in Rajasthan: one at Amvan and the other at Menal. The shrine from Amvan preserved three lintels with Ganeśa, Viṣnu and Sūrya occupying the central niches of the three lintels. ${ }^{74}$ In the case of Menal, the triple-celled shrine comprises the historic nucleus of the site.

\subsection{Irenic Śaivism}

The inscriptions from Kāman acknowledge a number of deities and shrines, but it is Śiva as Kāmyakeśvara who figures as the town's patron deity. Unfortunately, the inscriptions do not provide us with descriptions of the God or references to mythological events and narratives that might indicate how his devotees imagined him. For these clues we must rely on the iconography

74 This temple 3 has been studied in detail by Odette Viennot, who comments that the deities represented in the three shrines attest to the 'syncretic' religious landscape. While certainly diverse, the invocation of syncretism suggests a uniform move toward amalgamation that obscures the work of strategy and design in monumental architecture. While the intention or agency that informed the design of the structure may be impossible to recover that does not mean that we should deny its existence. Pia Brancaccio refers to the shrine as 'Vaishnava', a sectarian affiliation that is poorly evidenced. Odette Viennot, "Un type rare de temple à trois chapelles au site d'Āmvān (Rājasthān)," Arts Asiatiques 26 (1973): $125^{-1} 5^{6 .}$ 


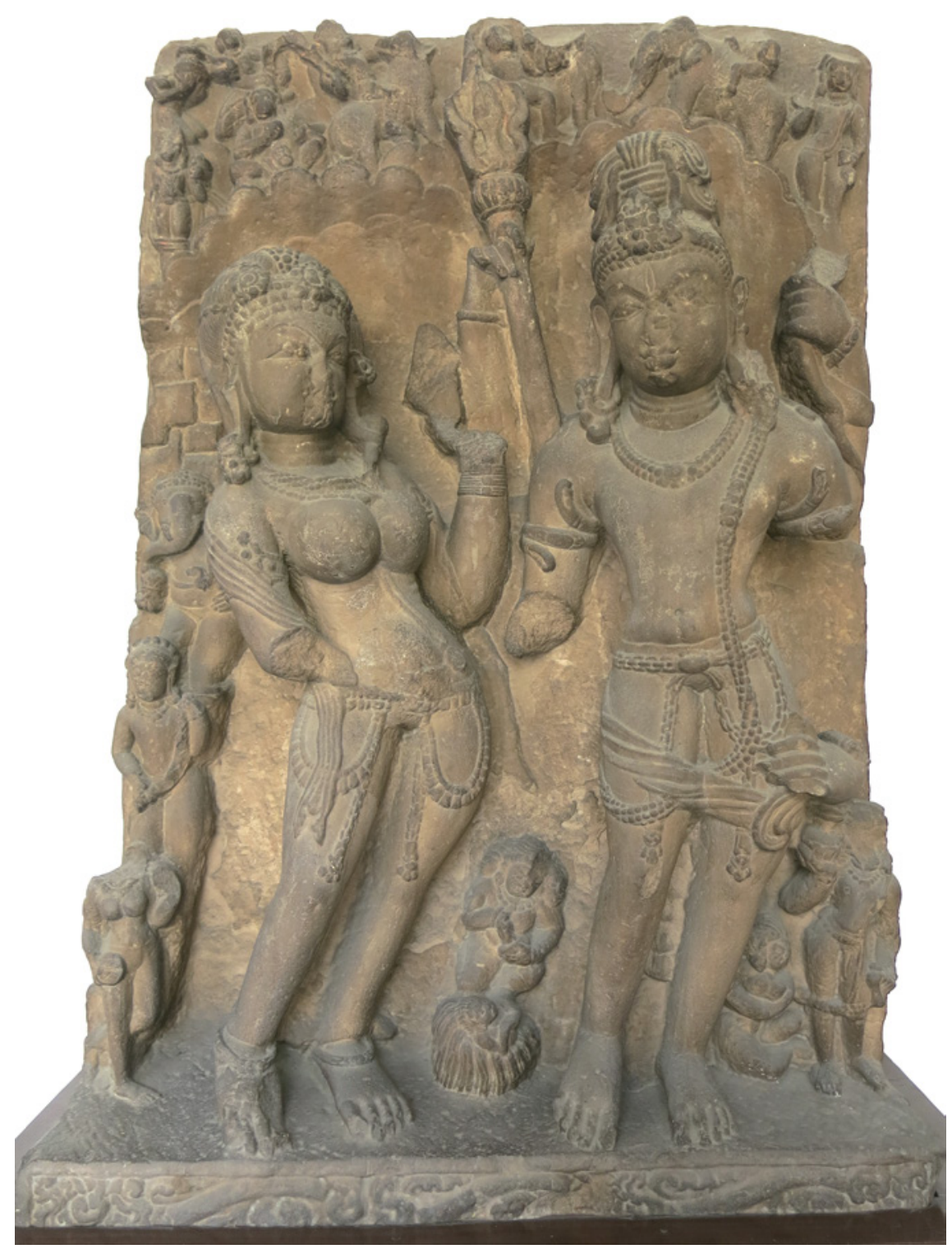

FIGURE 60 Kalyānasundara from Kāman, c. 9th century NATIONAL MUSEUM NEW DELHI

and, in this respect, the artists are remarkably consistent in their vision. All of the images I have identified from Kāman depict Śiva as a family man using two popular iconographic topoi: 1). his marriage to Pārvatī (Kalyānasundara) 


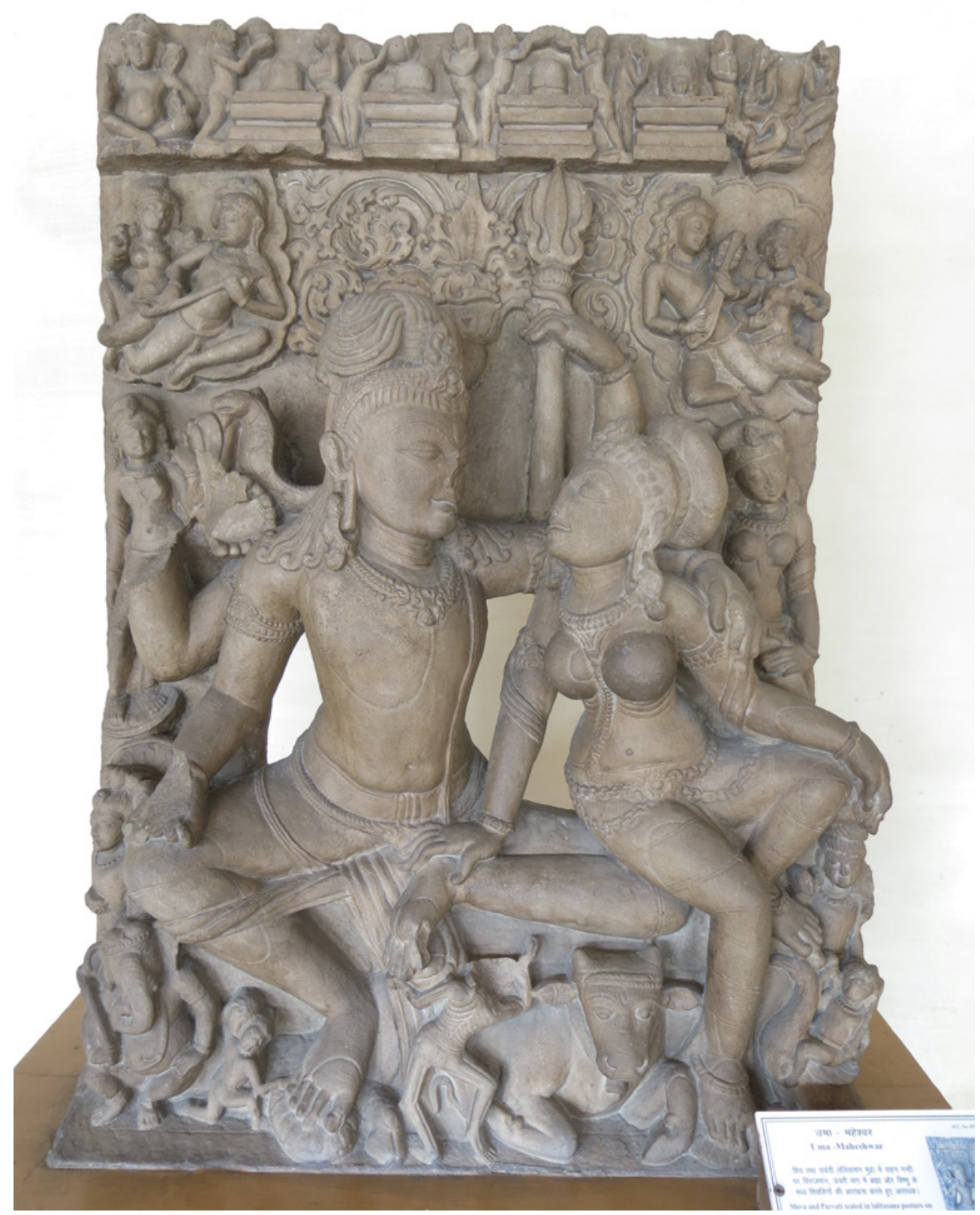

FIGURE 61

Umā-Maheśvara from Kāman, c. 9th-1oth century BHARATPUR GOVERNMENT MUSEUM 


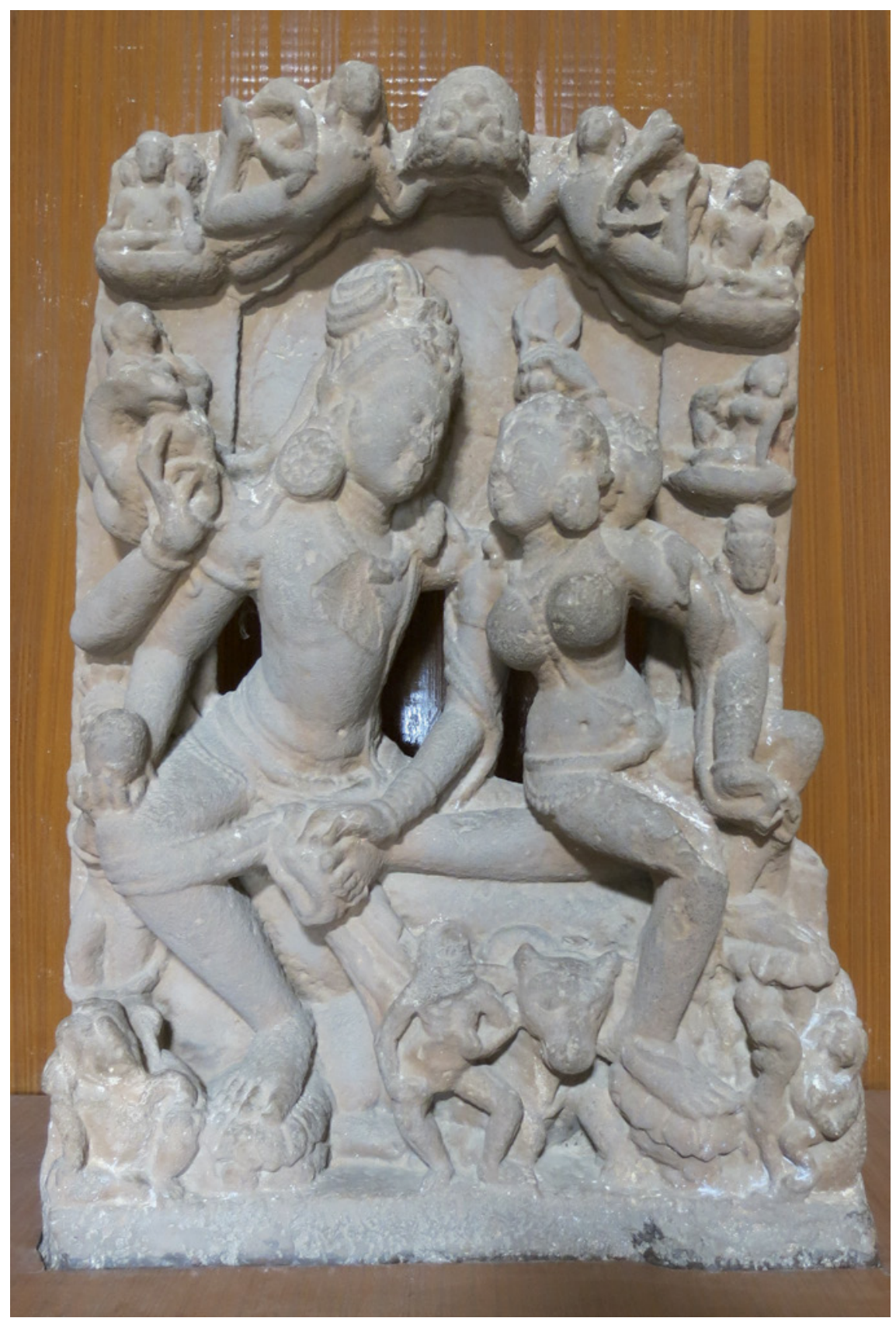

FIGURE 62

Umā-Maheśvara from Kāman, c. 9th-1oth century ALWAR GOVERNMENT MUSEUM 
and 2) the affectionate Umā-Maheśvara-type with Skanda and Ganeśa at the couple's feet [Figure 6o]. Neither of these visualizations is particularly unique for this time period or region. What is significant is that they are deployed exclusively and consistently in Kāman. This iconographic program communicates a distinctly irenic vision of Śaivism; that is, a peaceful, institutionalized, and socially supported religion. This articulation of Śaiva religiosity stands in marked contrast to nearby sites like Harșa. The cult site of the Cāhamāna clan ruling from Śakāmbarī, Harșa was similarly a centre of early Śaiva, and specifically Pāśupata activity. The iconographic program at Harșa, however, includes images of Bhairava and other fearsome depictions of Śiva, groups of yoginīs adorned with garlands of skulls, and scenes suggestive of asceticism and penance-notably, icons of Pārvatī performing the 'five-fire penance' (pañcāgnitapas). In my visits to the site, storerooms, and regional museums I have not found a Kalyānasundara or Umā-Maheśvara icon from Harșa.

Among the collection of sculptures from Kāman, one image stands out as particularly unique: an Umā-Maheśvara image now displayed in the Bharatpur museum and dated to the 1oth century [Figure 61]. This image is nearly identical to a contemporaneous icon now in the Government Museum in Alwar [Figure 62]. Both images are comprised of three registers, with depictions of the divine couple occupying the center and their figures emphasized through the use of negative space. In both, Śiva and Pārvatī are turned toward each other in a loving gaze. Ganeśa and Skanda occupy the bottom register on the left and right and Śiva's bull and the skeletal Bhṛngin occupy the centre. Attendants flank the pair. Siva also holds a round object in his proper right hand in the Alwar image. Although damaged, in the Bharatpur sculpture Siva appears to be holding a similar item. This could have been a sitaphal, the seed-filled fruit that becomes a popular attribute of Lakuliśa, although these fruits are typically represented as more conical in shape and with a striated or bumpy exterior. This smooth round object recalls the ball of earth that is an attribute of Hindu creator deities in Khmer and South Indian sculpture. In both of the images, Śiva's yogapatța, a visual gesture to his ascetic persona, remains visible to us, but his gaze is fixed on his beautiful wife.

The notable difference between the two images is evident in the upper register of the icons. I will discuss the Alwar icon first and contrast it with the Bharatpur icon below. Of the two, the Alwar icon conforms to popular iconographic convention. Brahmā and Viṣnu appear in the upper left and right corner. The center depicts two celestials or vidyädharas elevating a linga. The base 

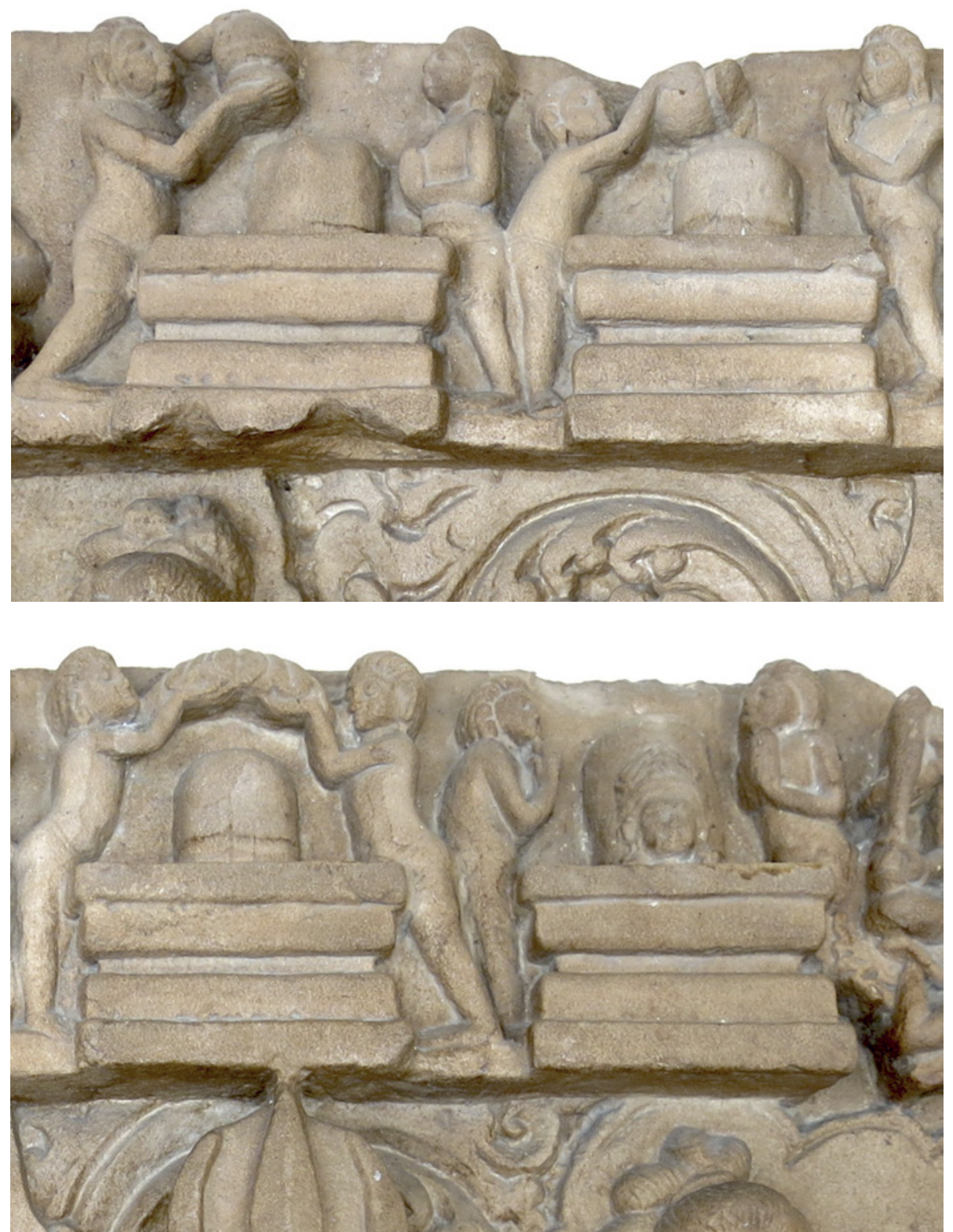

FIGURE 63

Umā-Maheśvara, linga pratiṣṭā panel, close view 
of the linga is encircled by a garland with an ornament or decorative element in the middle. This visual reference to Siva's phallic emblem occupies the celestial upper register of the image where it appears at the center of the composition along with the other major deities Brahmā and Viṣnu. This elevated position could be interpreted as an indication that the linga here represents a more abstract form that, while clearly revered, is not the focus of devotional attention. That attention is directed toward the large central panel where the anthropomorphic Siva and the Goddess are shown in an embrace. This focus on the divine couple also suggests the importance of the Goddess in the region, as well as a preference for the anthropomorphic image of the deity. When displayed in the exterior niche of a temple or in an elevated space for worship, the devotee's gaze would fall first on the lower register occupied by Śiva's 'children', the affiliated and attendant deities that comprise his entourage. Moving upward, the eye of the viewer would then fall on the Lord's feet - the left foot clasped affectionately by the goddess - then on the divine couple, and culminate with the elevated and more abstract manifestation of the deity in the linga. In this way, the Lord moves from concrete to abstract through the vertical composition.

When compared to the Alwar sculpture, the Bharatpur icon seems, at first glance, to depict a similar scene. The lower and center registers are nearly identical, as was mentioned above. It is in the upper most panel that the latter tells a more complicated story [Figure 63]. Rather than a single linga held aloft, the artists here present four consecutive scenes of a linga under active worship by a pair of devotees. When viewed from left to right, I argue that these icons were intended to represent a progression, a series of devotional acts that effect the presence of the deity in the object-i.e. the scene depicts a pratișthā. The linga, on the far left, rough and unfinished, gradually expands, the edges are smoothed, and the characteristic markings emerge in the second scene and are distinct in the third scene. The fourth scene witnesses the culmination of this process: the object is fully enlivened and the face of the deity emerges from the linga.

Viewed as a discrete element, this panel represents the efficacy of the ritual actions undertaken by the two devotees-likely temple priests and not ascetics judging by their appearance-whose acts of lustration and garlanding appear as the catalyst for the formation of the linga as a discernable object and visible manifestation of the deity. But how was this vision intended to inform the viewer's reading of the central panel and vice versa? There are certainly 
multiple layers of scrutability in this image: didactic, rhetorical, proscriptive. We could, for example, read the upper panel as instructive- that is, a scene that outlines a recommended course of ritual action and its efficacious result. The motivation for undertaking this action can be inferred from the center panel, which depicts a peaceful and well-disposed Lord with his entourage. In this interpretation, the ritual is an act of pacification or propitiation that makes the irenic scene possible. A second possibility is to understand this icon as articulating a comprehensive and inclusive vision of Śaiva religiosity. The devotee may access the Lord through his affiliated deities located in the lower register or through worship of his more abstract form, as seen in the upper panel. Yet, the focus of both the artists' and the audience's attention is the central panel in which the happy partnership of Śiva and Devĩ is emphasized. This is not an image of power or military might designed to intimidate; rather, it is an image of comfort and affection intended to materialize the laukika aspirations of Kāman's working class.

Conclusions

As with the other prestigious places pinpointed in the SP mapping of the Pāsupata landscape, Sapādalakṣa was integral to the regional nexus of settlement, commerce, and politics. Epigraphic and material evidence from the region provides compelling evidence to posit that this area was of foremost significance for the institutionalization of Śaivism in the early medieval period. Rather than Imperial powers, rulers of what I have termed 'emplaced polities' were instrumental in the development of temple-centered religion. These temples were not simply places of worship, but institutions through which new social sodalities and communities were constituted. The richness of the iconography and the variety in the structural articulation of the religious monuments similarly reflects the wide range of religious concerns and practices that were accommodated within what were ostensibly ‘Śaiva' spaces.

The success, and indeed dominance, of Śaivism in this particular region was tied to these powerful places where networks of political elites, religious specialists, and economic actors converged. In light of this evidence, one could ask if Sapādalakșa was the site of Jambumārga? My working hypothesis that the large settlement excavated near the Sambhar Salt Lake could correspond to 
this purānic locale is certainly speculative, but the chronology of the site confirms that it was thriving at the around the same time the text was composed. And like the Jambumārga of the SP, the importance of Sambhar declined after the $7_{\text {th }}$ century when the regional political and economic networks moved north. 